\title{
PRINCIPAIS AFECÇÕES RESPIRATÓRIAS DE BOVINOS LEITEIROS
}

\author{
MAIN RESPIRATORY CONDITIONS OF DAIRY CATTLE
}

Camila Freitas Batista ${ }^{1}$ e Raysa Brenda Marques Maia2 ${ }^{2}$

Universidade Cruzeiro do Sul (UNICSUL) e Veterinary Clinical Immunology Research Group.

Faculdade de Medicina Veterinária e Zootecnia da Universidade de São Paulo (FMVZ/USP) e Veterinary Clinical Immunology Research Group.

Autor para correspondência:

camila.batista@cruzeirodosul.edu.br

Revista Brasileira de Buiatria Clínica Médica, Volume 1, Número 8, 2021

ISSN 2763-955X

DOI:10.4322/2763-955X.2021.008

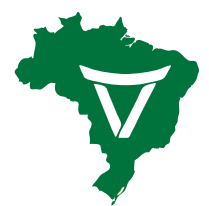

Associação Brasileira de Buiatria

\section{RESUMO}

As doenças respiratórias representam grande preocupação em todas as fases produtivas na pecuária. Bovinos de todas as idades estão susceptíveis, e em alguns ambientes de produção, as doenças respiratórias são a causa mais importante de morbidade e mortalidade de animais. Entretanto estas enfermidades representam grandes desafios principalmente em bezerros. Dentre as afecções mais recorrentes é o Complexo Doença Respiratória dos Bovinos (CDRB). A doença respiratória bovina (DRB) é uma síndrome causada por vários fatores, incluindo estressores ambientais e relacionados ao manejo, além de patógenos virais e bacterianos. Ademais outras incorrem como problemática no controle sanitário do rebanho, como as pneumonias verminóticas e a tuberculose bovina. Este artigo objetiva descrever as condições e características das principais doenças respiratórias que acometem bovinos, bem como, diagnósticos e tratamentos que podem ser aplicados ao rebanho, elencar os fatores de risco e as medidas profiláticas, a fim de melhorar o bem-estar animal e reduzir as perdas econômicas.

Palavras-chave: bezerros, $\mathrm{CDRB}$, penumonia verminótica, tuberculose.

\section{ABSTRACT}

Respiratory diseases are a major concern in all production phases in livestock. Cattle of all ages are susceptible, in some production environments, respiratory diseases are the most important cause of morbidity and mortality in animals. However, these diseases represent major challenges, especially in calves. Among the most recurrent diseases is the Bovine Respiratory Disease Complex (CDRB). Bovine respiratory disease (BRD) is a syndrome caused by several factors, including environmental and management-related stressors in addition to viral and bacterial pathogens. In addition, others are problematic in the health control of the herd, such as verminotic pneumonia and bovine tuberculosis. This article aims to describe the conditions and characteristics of the main respiratory diseases that affect cattle, as well as diagnosis and treatment that can be applied to the herd and list the risk factors and prophylactic measures. In order to improve animal welfare and reduce economic losses.

Keywords: calves, BRDC, verminotic pneumonia, tuberculosis. 


\section{COMPLEXO DOENÇA RESPIRATÓRIA DOS BOVINOS (CDRB)}

\section{INTRODUÇÃO}

O impacto econômico da bovinocultura ao produto interno bruto é indiscutível e gerou lucro bruto de aproximadamente $\mathrm{R} \$ 67$ bilhões em 2019. Neste mesmo ano o rebanho composto por mais de 214,7 milhões de bovinos, permitiu o abate de 32,44 milhões de cabeças e a produção de 34,8 bilhões de litros de leite ${ }^{1}$. Neste contexto, a perda de bezerros representa prejuízo considerável, pois além da sua morte comprometer as taxas de reposição, impede o retorno do investimento na concepção e nascimento, muitas vezes expressivo.

As taxas de mortalidade de bezerros nos EUA podem chegar a $30 \%$ entre o nascimento e dezesseis semanas de vida ${ }^{2}$, sendo as doenças respiratórias a segunda maior causa dessas perdas, perdendo apenas para as diarreias. No Brasil não existem dados atualizados sobre as taxas de morbidade e mortalidade de bezerros em fase de aleitamento. A mortalidade pós-natal de bezerros de rebanhos leiteiros pode ser influenciada pelo tamanho do rebanho, pelo manejo do colostro e do aleitamento, pelo local onde são criados, pela idade de acesso ao concentrado e pelo período de desmame ${ }^{3}$.

Dentre as enfermidades infecciosas que acomentem bovinos jovens, as do sistema respiratório estão entre as maiores causas de perdas econômicas em âmbito mundial ${ }^{3}$. Calcula-se que aproximadamente $25 \%$ dos bezerros apresentam, pelo menos uma vez, um episódio de doença respiratória durante o primeiro ano de vida ${ }^{5}$. As maiores taxas de mortalidade de bezerros são registradas ao longo do primeiro mês de vida ${ }^{6}$, sendo a broncopneumonia considerada como um grande desafio, atingindo $12,7 \%$ de bezerros criados em sistema extensivo, e constituindo 23,9 \% das afecções que acometem bezerros com até um ano de idade ${ }^{7}$.

Dentre as afecções do sistema respiratório, a mais comum é o Complexo Doença Respiratória dos Bovinos $(\mathrm{CDRB})^{8}$. Possui etiologia multifatorial e qual- quer estímulo estressante pode afetar adversamente o sistema imune do hospedeiro, e o aumento dessa susceptibilidade pode favorecer infecções, até mesmo por microrganismos oportunistas ${ }^{9-12}$.

\section{ETIOPATOGENIA}

Estruturalmente os pulmões dos mamíferos são divididos em três tipos, o bovino possui pulmão Tipo I, um órgão com alta densidade colágena e lobulações bem delimitadas, o que favorece a baixa disseminação de patógenos, em contrapartida, dificulta a saída dele, assim como a entrada de agentes terapêuticos.

Por apresentarem esse tipo de pulmão, o processo pneumônico predominante são as broncopneumonias, classificação dada pelo local de origem do processo inflamatório-infeccioso, nesse caso a junção bronquíolo-alveolar. A principal causa do acometimento desse local é a abrupta diminuição da velocidade do fluxo de ar, permitindo a sedimentação de partículas entre 0,2 e 0,5 $\mu \mathrm{m}$. Contribuindo para a instalação da inflamaçãoinfecção nesse local, está o fato de não apresentar defesa mucociliar e macrófagos, que estão presentes nos alvéo$\operatorname{los}^{13}$.

As broncopneumonias possuem predominantemente localização crânio-ventral, devido à menor extensão das vias respiratórias que suprem essa região, diminuindo a eficiência na filtragem do ar pela camada mucociliar. Nesta região também ocorre maior turbilhonamento do ar, o que pode gerar maior desgaste do epitélio, e por fim, a ação da gravidade; dificulta a eliminação das partículas infecciosas e exsudatos dessas porções do pulmão.

Apesar da diversidade etiológica do CDRB, existem peculiaridades atribuidas a Mannheimia baemolytica (anteriormente denominada Pasteurella haemolytica $^{14}$, habitante normal da nasofaringe de bovinos, que nas situações de menor efetividade dos mecanismos de defesa do trato respiratório, atinge o trato respiratório 
posterior, causando a Mannheimiose Pneumônica Bovina $(\mathrm{MPB})^{15-18}$. E mesmo sendo oportunista, a $M$. haemolytica causa pneumonias graves, normalmente acompanhadas de exsudato fibrinonecrótico e hemorragia alveolar $^{19-21}$.

Exemplos de mecanismos de defesa comprometidos incluem, danos às células que revestem o trato respiratório anterior por vírus, tais como Vírus da Rinotraqueíte Infecciosa Bovina (IBR), Vírus da Parainfluenza-3 (VPI-3), ou Vírus Sincicial Respiratório Bovino (VSRB). Danos ao revestimento traqueal também podem ocorrer, devido às substâncias irritantes inaladas como amônia ou poeira. $\mathrm{O}$ mecanismo de defesa respiratória também pode ser deprimido devido à imunossupressão associada com Diarreia Viral Bovina $(\mathrm{BVD})^{22}$.

Outro importante aspecto a ser considerado é a mudança da efetividade das células imunes relacionadas à idade ${ }^{22-25}$.Assim, os estudos tornam-se mais relevantes quando envolvem animais acima de seis meses de idade, pois se observa o efeito do patógeno nas células imunes maduras, portanto, a partir desta idade os bovinos podem ser estudados como modelos representativos da suscetibilidade de animais adultos a CDBR, ou seja, bovinos em sistemas de alta tecnificação, como grandes confinamentos e lotes de animais desmamados sobre alta pressão social ${ }^{26}$.

\section{EPIDEMIOLOGIA}

As características específicas do pulmão dos bovinos, estão resumidos como se segue: o pulmão esquerdo consiste em dois lóbulos (lobo cranial, que é dividido em dois segmentos, e lobo caudal), enquanto o pulmão direito consiste em quatro lóbulos (lobo cranial, lobo médio, lobo caudal e lobo acessório). Ao contrário da anatomia do pulmão da maioria dos outros mamíferos, o ramo do brônquio do lobo cranial direito (brônquio traqueal) sai diretamente da lateral direita da traqueia $^{27}$.

A anatomia do pulmão bovino contribui para a instalação de doenças infecciosas, pois apresenta elevado grau de lobulação e percentagem de tecido intersticial que conduz uma relativa baixa complacência pulmonar específica e maior resistência do tecido pulmonar. Esse elevado grau de lobulação leva à forte independência dos segmentos. Assim, os processos inflamatórios são limitados por septos de tecido conjuntivo, entre segmentos doentes e saudáveis, e muitas vezes encontram-se dentro do mesmo lobo ${ }^{27}$. Resumindo, as caracteristicas do sistema respiratório dos bovinos que compreendem as vias aéreas estreitas, caixa torácica muito rígida, volume pulmonar pequeno e a compartimentalização pulmonar, são responsáveis por trocas gasosas menos efetivas, atividade macrofágica alveolar mais lenta e menor velocidade de limpeza pulmonar em comparação à outros mamíferos facilitando a entrada do patógeno, e dificultando a sua saída, aumentando a possibilidade de causar uma doença ${ }^{10,12,14}$.

Apesar dessa susceptibilidade anatômica, o trato respiratório de um bovino saudável tem vários mecanismos que impedem os microrganismos patogênicos de colonizar os tecidos expostos, incluindo produção de muco e os cílios, para interceptar e remover fisicamente microrganismos e partículas estranhas, a resposta imune da mucosa, e a manutenção de uma população simbiótica de bactérias comensais em região anterior do sistema respiratório ${ }^{10}$.

Porém, quando infectados por patógenos respiratórios primários, como os vírus (VSRB, VPI-3, Herpes Vírus Bovino tipo I) ${ }^{28-30}$, as defesas respiratórias do hospedeiro ficam prejudicadas, e microrganismos comensais do trato respiratório anterior e nasofaringe de ruminantes saudáveis podem se tornar patogênicos oportunistas, sendo os mais comuns Pasteurella multocida, Histophilus somni, M. haemolytica e Mycoplasma bovis ${ }^{14,31,32}$. Outros fatores, incluindo o estado nutricional, estresse e qualidade do ar também podem desempenhar papéis que prejudicam os mecanismos de defesa do hospedeiro ${ }^{10,33}$.

Dentre estes agentes etiológicos destaca-se a 
M. haemolytica, por ser a principal bactéria isolada de bovinos com doença respiratória ${ }^{4,17,34-36}$ que causa pneumonia lobar fibrinonecrótica e pleuropneumonias em bovinos $^{34}$, considerada a mais patogênica associada ao $\mathrm{CDRB}^{4,17,37}$ e por causar grandes danos à pecuária mun$\operatorname{dial}^{34}$.

A M. haemolityca faz parte da microbota nasofaríngea de bovinos, animais que em sistuações de estresse não desenvolvem a mannheimiose geralmente apresentam os sorotipos apatogênicos $\mathrm{S} 2$ e $\mathrm{S} 4$, enquanto animais que desenvolvem a doença tem predomínio do sorotipo patogênico S1. Este possui fatores de virulência como a leucotoxina e o LPS. Em casos de infecç̧ão por P. multocida, as lesões são mais brandas do que a infecção por M. haemolityca ${ }^{13}$.

Dentre os principais fatores predisponentes para a ocorrência do CDRB estão o agrupamento de muitos animais (superlotação), agrupamento de animais de diferentes faixas etárias, excesso de umidade, baixas temperaturas, evaporação de substâncias irritantes como amônia, que diminuem a eficiência de lençol mucociliar e dos macrófagos alveolares ${ }^{38}$. Além destes, aspectos inerentes ao animal como desidratação, esforço físico, quadros de acidose e fatores estressantes como; transporte, descorna, desmame, mudança de lotes, castração, entre outros manejos podem contribuir para ocorrência da enfermidade..

Apesar do agrupamento ser um fator de risco, agrupar bezerros per se não significa necessariamente maior incidência de doenças respiratórias, se for feito de maneira adequada pode favorecer o desenvolvimento das bezerras. Nordlund e Halbach ${ }^{38}$ afirmam que a maioria dos criadores utilizam o sistema de bezerras criadas em baias ou cabanas individuais, principalmente por causa da percepção de maior ganho de peso, menor incidência de doenças e redução de problemas comportamentais, como suç̧ão cruzada. No entanto, essas suposições foram contestadas e agora parece que amamentar bezerros em pares é preferível porque bezerros criados individualmente tendem a ter habili- dades de aprendizagem mais pobres, mostram habilidades sociais deficientes e têm dificuldade em lidar com novas situações, enquanto bezerros criados socialmente têm melhor ingestão de alimentos sólidos antes do desmame e melhor ganho de peso antes e depois do desmame. Com taxas de crescimento equivalentes durante o período de amamentação, bezerros emparelhados passam pela fase de desmame com menos contratempo do que bezerros criados sozinhos ${ }^{38}$.

\section{MANIFESTAÇÕES CLÍNICAS}

Independente do agente causador, as manifestações são semelhantes e frequentemente inespecíficas. $\mathrm{Na}$ broncopneumonia aguda, são achados frequentes: secreção nasal e ocular serosas, febre elevada, depressão, anorexia, perda de peso, taquicardia e relutância para deitar-se. Posição ortopneica, aumento da intensidade dos ruídos respiratórios normais, alteração na profundidade e outras características da respiração, tosse, crepitação, submacicez à percussão. Nos estágios avançados, é comum a detecção de intensa dispneia, com gemido expiratório ${ }^{2}$.

A auscultação do tórax antes e após a tosse pode revelar sons crepitantes e ásperos sugerindo a presença de exsudato nas vias aéreas. A constatação de taquipneia, dispneia mista ou expiratória, submacicez ou macicez à percussão e a auscultação de áreas aumentadas de ruído traqueobrônquico, broncobronquiolar rude e área de silêncio são sinais mais específicos de comprometimento do parênquima pulmonar. Secreção nasal pode ou não estar presente conforme a quantidade de exsudato nos bronquíolos e a existência ou não de inflamação do trato respiratório superior, e o odor da respiração pode ser fétido devido ao cheiro de pus em decomposição em grandes quantidades nas vias aéreas ${ }^{2}$.

Buscando facilitar a identificação da doença respiratória em bezerros, principalmente para evitar a instituição tardia de tratamentos, alguns pesquisadores desenvolveram métodos de triagem para identificação 
rápida de animais que mereçam atenção em relação à doença respiratória. Esses métodos envolvem escores para temperatura retal, tosse, presença de secreção nasal e ocular e posicionamento de cabeça e orelha, de acordo com a presença ou ausência de manifestações recebe uma pontuação, que indica se esse animal está ou não com doença respiratória ${ }^{39,40}$ (Quadro 1). Embora estes métodos ainda não terem sidos validados em países tropicais, podem ser utilizados como forma de auxílio na triagem do CDRB.

Quadro 1.Escore de Detecção de Doença Respiratória em Bezerros, adaptado deMcGuirk ${ }^{39}$.

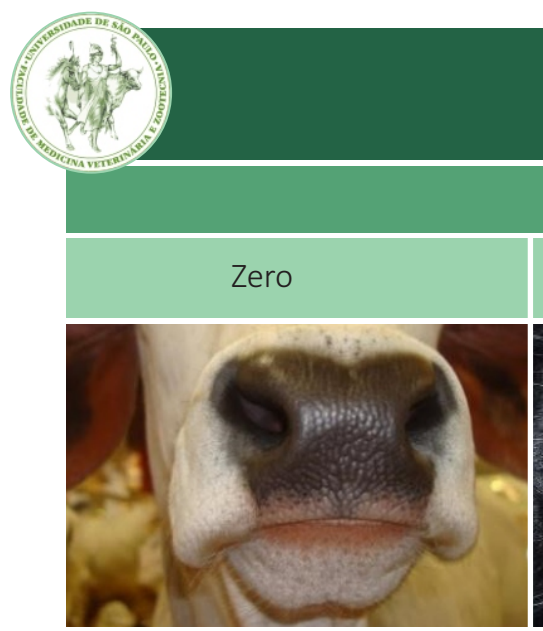

Normal

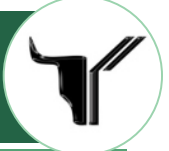

\section{Descarga Nasal}

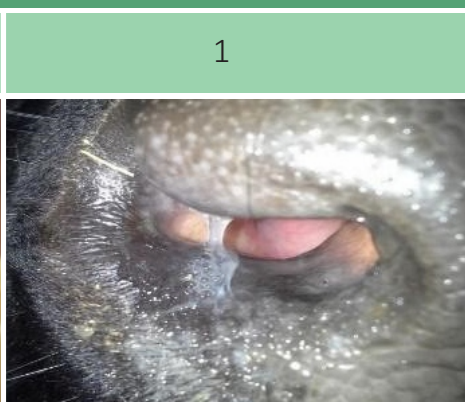

Serosa

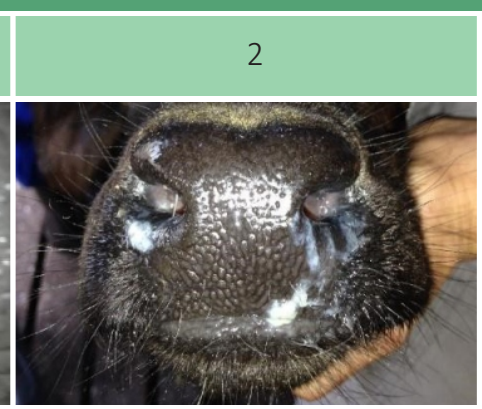

Mucosa

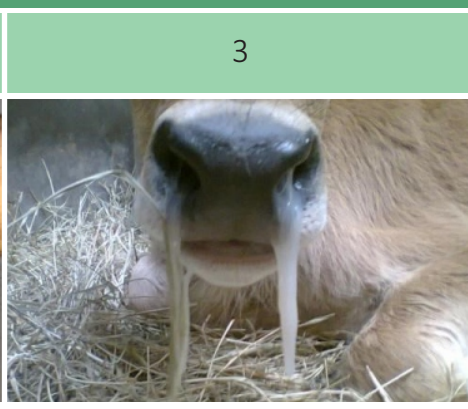

Mucopurulenta

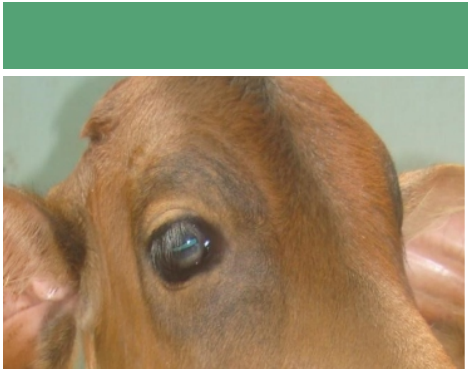

Normal

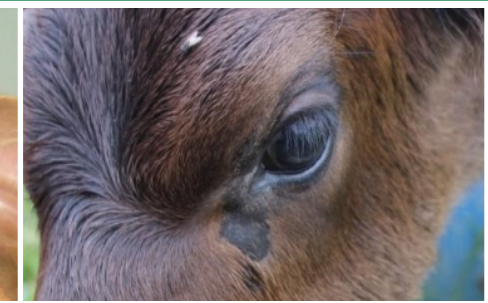

Serosa

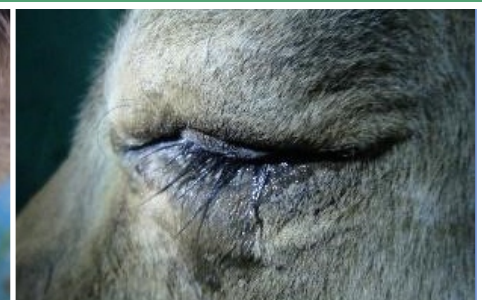

Mucosa

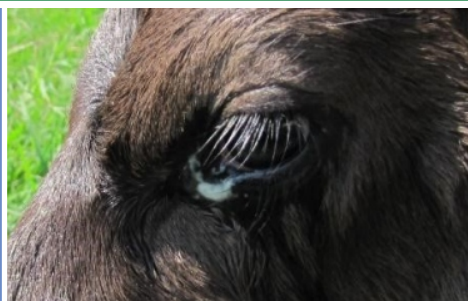

Mucopurulenta

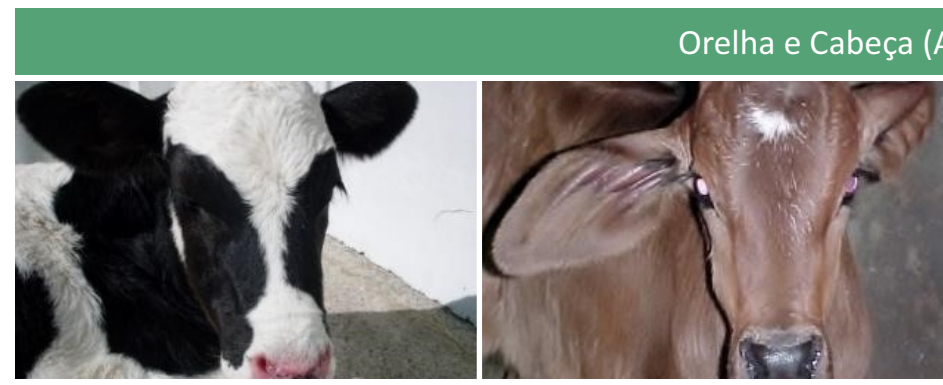

Normal
Agitar de orelhas e balançar de cabeça

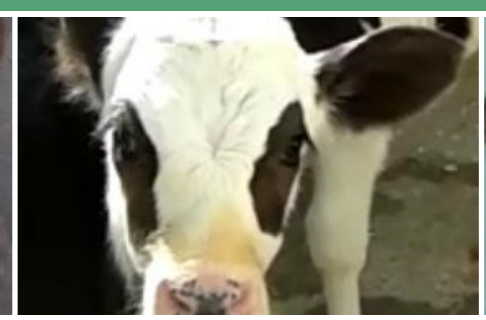

Inclinação unilateral ligeira

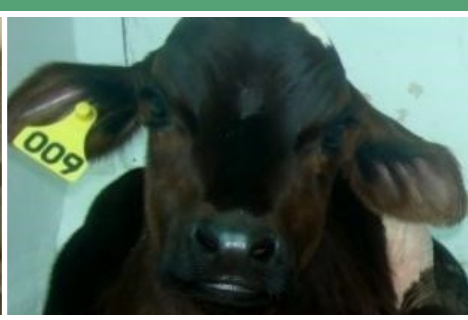

Inclinação de cabeça ou orelha bilateral

Temperatura

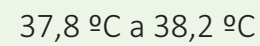

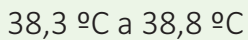

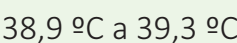

$\geq 39,4$ 으
Tosse

Sem tosse

Quando induzida

Ocasional espontânea

Frequente espontânea

Fonte das imagens: VetImmunology (2015). 


\section{DIAGNÓSTICO E EXAMES COMPLEMENTARES}

Observar o comportamento dos animais ainda é considerada a principal forma de rastrear, em um rebanho, quais estão apresentando algum tipo de alteração, sendo que a observação de tosse, respiração abdominal anormal e secreção nasal auxilia no diagnóstico da doença respiratória ${ }^{39,45}$ Essas alterações acompanhadas do aumento das frequências cardíaca e respiratória e da temperatura retal podem confirmar o diagnóstico $^{12,46,47}$.

Porém, algumas vezes animais aparentemente sadios podem estar acometidos por alguma doença respiratória, não sendo possível estabelecer o diagnóstico correto e precoce, sendo necessário o emprego de métodos semiológicos tradicionais ${ }^{48}$. $\mathrm{O}$ exame físico, em particular a auscultação pulmonar, nem sempre é elucidativa para a doença respiratória, e o diagnóstico definitivo requer exames complementares mais específicos como ultrassonografia, radiografia, broncoscopia ou análises citológicas e microbiológicas do trato respiratório (Figura 1$)^{49-53}$.

Tais exames podem auxiliar na detecção dos agentes infecciosos, no delineamento do perfil de resposta do sistema respiratório, no grau da lesão, e local acometido, favorecendo a melhor escolha da terapia a ser utilizada e a obtenção de um prognóstico mais preciso $^{24,54-56}$.

Exames simples como um hemograma quando realizado em um ou mais animais, pode ajudar a determinar o estágio de evolução da doença e, algumas vezes, o principal agente causal, se bacteriano ou viral. O proteinograma sérico pode ser útil no monitoramento da evolução da pneumonia de bezerros causada por $M$. haemolytica, pois as concentrações de proteínas de fase aguda se elevam rapidamente após a infecção ${ }^{46,57}$.

Análises microbiológicas, citológicas e imunológicas das secreções do trato respiratório são importantes no auxílio ao diagnóstico e na determinação do estadiamento da doença ${ }^{49,53}$, uma vez que o sucesso do tratamento da doença está intimamente relacionado ao seu diagnóstico precoce e o reconhecimento do agente etiológico ${ }^{51,54}$.

Além das técnicas de coleta do lavado para citologia e exame microbiológico podemos realizar ainda a inspeção indireta das vias aéreas por broncoscopia (Figura 1H). Esta técnica é excelente por permitir direcionar e selecionar os locais de lavagem, além de proporcionar a visibilização direta das vias aéreas ${ }^{58,59}$. A endoscopia de trato respiratório de grandes animais é de grande auxílio no diagnóstico das doenças do sistema respiratório, nos últimos anos a endoscopia tem sido mais explorada na medicina bovina ao ponto de ser considerada rotineira por alguns autores ${ }^{60,61}$.

Para assegurar um tratamento eficaz da doença, veterinários e pesquisadores precisam confirmar a presença do agente e determinar a sensibilidade a antimicrobianos, durante surtos de CDRB nas explorações e em estudos clínicos ${ }^{44,56}$.

Para essa finalidade, diferentes métodos de colheita são utilizados, tais como suabe nasal ${ }^{35,62}$ ou nasofaríngeo ${ }^{44,62}$, lavado traqueobrônquico ${ }^{43,50,51}$ ou lavado broncoalveolar ${ }^{51}$ (Quadro 2).

A coleta e a avaliação de secreções traqueobrônquicas e broncoalveolares é uma técnica útil para identificar doença das vias respiratórias posteriores, principalmente para determinar a etiologia da pneumonia (viral, bacteriana, por Mycoplasma sp., fúngica ou parasitária) ou da gravidade da enfermidade (avaliando o perfil citológico das secreções coletadas) ${ }^{2}$. O exame citológico do fluido recuperado pode fornecer informações valiosas acerca da gravidade, da extensão e da etiologia da doença das vias respiratórias posteriores $^{24,50,51,53}$.

Cada método de coleta de amostra produz fluido de características e fontes diferentes, e a interpretação dos resultados depende da sua fonte e do método de coleta. Apesar das limitações mencionadas, os diag- 

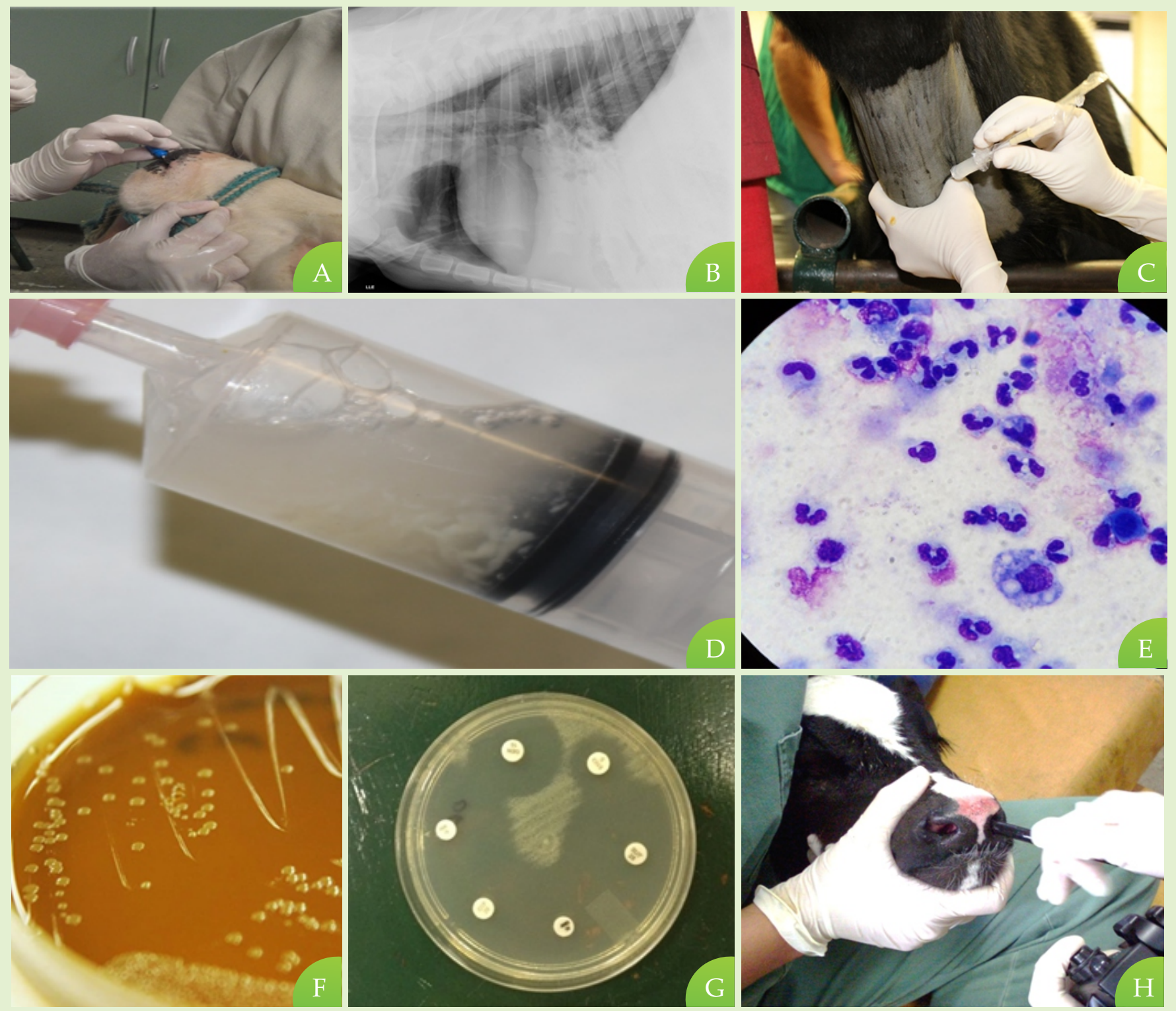

10
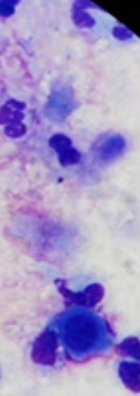

$\mathrm{D}$
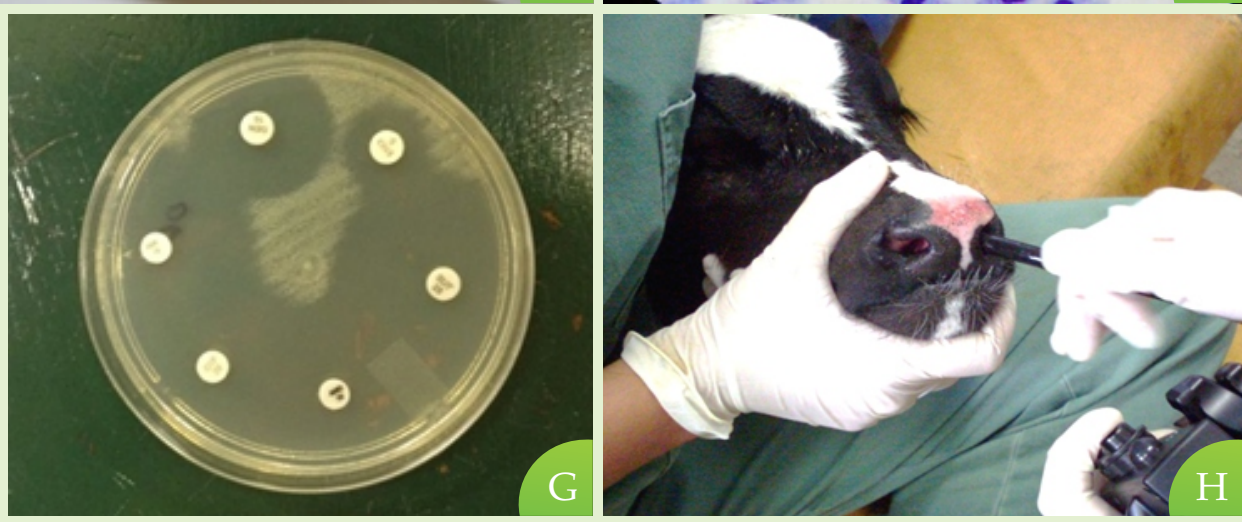

Figura 1: Exames complementares para dia gnóstico de afecções respiratórias. (A) Suabe nasal,(B) exame radiográfico de bezerro com broncopneumonia, (C) lavado traqueobrônquico pela técnica transtraqueal, (D) amostra de lavado traqueobrônquico de animal com broncopneumonia, (E) citologia de amostra de lavado broncoalveolar de bezerro com broncopneumonia bacteriana (presença predominante de neutrófilos), (F) cultura em BHI sangue de colônias de M. baemolytica isolada de bezerro com mannheimiose, $(\mathrm{G})$ antibiograma e $(\mathrm{H})$ exame endoscópico para a coleta de lavado broncoalveolar e inspeção indireta das vias respiratórias.

nósticos são cada vez mais usados quando se trata da doença respiratória bovina. Esse aumento do uso é compreensível, pois a tomada de decisão antimicrobiana para CDRB ainda envolve frequentemente a decisão de usar terapia de grupo e, atualmente, devido à importância do uso racional de antimicrobianos, a medicação em massa sem qualquer evidência da neces- sidade dessa terapia é cada vez mais criticada ${ }^{63}$.

Estudos comparando o lavado broncoalveolar (LBA), lavado traqueobrônquico (LTB), suabe nasal profundo (SNP) e LBA por endoscopia tem sido feitos para avaliar prós e contras de cada um deles ${ }^{63,64}$. A escolha vai depender da finalidade desejada (isolamento do agente, estadiamento da doença) e da disponibilidade 
Quadro 2: Visão geral das técnicas de amostragem disponíveis do trato respiratório de bezerros e bovinos, com vantagens e desvantagens.

\begin{tabular}{|c|c|c|c|c|}
\hline & $\begin{array}{c}\text { Suabe nasofaríngeo } \\
\text { de Bezerros }\end{array}$ & $\begin{array}{c}\text { Lavagem transtraqueal } \\
\text { ou aspirado } \\
\text { transtraqueal }\end{array}$ & $\begin{array}{l}\text { Lavagem } \\
\text { broncoalveolar não } \\
\text { endoscópica }\end{array}$ & $\begin{array}{l}\text { Lavagem } \\
\text { broncoalveolar } \\
\text { endoscópica }\end{array}$ \\
\hline $\begin{array}{c}\text { Local de } \\
\text { amostragem }\end{array}$ & $\begin{array}{c}\text { Mucosa } \\
\text { nasofaríngea }\end{array}$ & $\begin{array}{l}\text { Bifurcação } \\
\text { traqueal }\end{array}$ & $\begin{array}{l}\text { Lobo pulmonar } \\
\text { aleatório individual }\end{array}$ & $\begin{array}{l}\text { Lobos pulmonares } \\
\text { individuais (ou } \\
\text { múltiplos) direcionados }\end{array}$ \\
\hline Uso & $\begin{array}{l}\text { Uso único, } \\
\text { descartável }\end{array}$ & $\begin{array}{l}\text { Uso único, descartável } \\
\text { ou uso múltiplo, } \\
\text { esterilizável }\end{array}$ & $\begin{array}{l}\text { Uso múltiplo, } \\
\text { esterilizável }\end{array}$ & $\begin{array}{l}\text { Uso múltiplo, } \\
\text { esterilizável }\end{array}$ \\
\hline $\begin{array}{l}\text { Representante das vias } \\
\text { aéreas posteriores }\end{array}$ & $\begin{array}{l}\text { Certa } \\
\text { representatividade } \\
\text { quando profundo }\end{array}$ & Sim & $\begin{array}{c}\text { Sim, } \\
\text { mas controverso }\end{array}$ & Sim \\
\hline Superfície amostrada & $<0,5 \mathrm{~cm}^{2}$ & 5 a $10 \mathrm{~cm}^{2}$ & $>10 \mathrm{~cm}^{2}$ & $>10 \mathrm{~cm}^{2}$ \\
\hline Custos de procedimento & - & ++ & + & ++++ \\
\hline $\begin{array}{c}\text { Tempo estimado do } \\
\text { procedimento/animal, } \\
\text { incluindo preparação (min) }\end{array}$ & -1 & 10 & 1 a 10 & 10 \\
\hline $\begin{array}{l}\text { Risco de contaminação } \\
\text { por via nasal }\end{array}$ & Alto & Ausente & $\begin{array}{c}\text { Moderado } \\
\text { (manga protetora } \\
\text { ou tampão de ágar } \\
\text { possível) }\end{array}$ & $\begin{array}{c}\text { Baixo } \\
\text { (manga protetora ou } \\
\text { tampão de ágar } \\
\text { possível) }\end{array}$ \\
\hline Dificuldade da técnica & - & + & + & ++ \\
\hline $\begin{array}{c}\text { Possíveis } \\
\text { complicações }\end{array}$ & $\begin{array}{l}\text { Hemorragia nasal } \\
\text { Fratura da haste } \\
\text { do suabe }\end{array}$ & $\begin{array}{c}\text { Enfisema } \\
\text { subcutâneo } \\
\text { Infecção da ferida } \\
\text { Hemorragia local } \\
\text { Ruptura acidental do } \\
\text { cateter por retração } \\
\text { sobre a agulha e } \\
\text { perda intratraqueal } \\
\text { da parte restante } \\
\\
\text { Desconforto } \\
\text { respiratório causado } \\
\text { por aspiração } \\
\text { insuficiente de fluido } \\
\text { instilado }\end{array}$ & $\begin{array}{l}\text { Hemorragia nasal } \\
\text { Hemorragia } \\
\text { intrapulmonar } \\
\text { Perfuração das vias } \\
\text { aéreas (apenas } \\
\text { cateter rígido) } \\
\text { Desconforto } \\
\text { respiratório } \\
\text { causado por } \\
\text { aspiração } \\
\text { insuficiente de } \\
\text { fluido instilado }\end{array}$ & $\begin{array}{l}\text { Hemorragia nasal } \\
\text { Desconforto } \\
\text { respiratório causado } \\
\text { por aspiração } \\
\text { insuficiente de fluido } \\
\text { instilado }\end{array}$ \\
\hline
\end{tabular}

Fonte: Traduzido de Pardon e Buczinski ${ }^{63}$.

do produtor (invasividade do exame, custo, e retorno em resultados) ${ }^{63}$.

Ao comparar as duas técnicas mais baratas e menos invasivas (SNP e LBA) Van Driessche et al. ${ }^{64}$ observaram que o LBA não endoscópico resulta em amostras menos contaminadas (e, portanto, mais facilmente interpretáveis) em comparação com o SNP. Nas condições em que o estudo foi realizado, obtiveram 
retorno de resultado interpretável em 79,2\% dos casos, em comparação com $31,2 \%$ no SNP, e melhores taxas de isolamento para $H$. somni, oferecendo melhor retorno do investimento para amostragem bacteriológica. Outra vantagem do LBA é que pode ser realizado rapidamente em um número representativo de animais a baixo custo e provavelmente tem menos impacto no bem-estar animal do que técnicas mais invasivas.

Quando realizamos a coleta com a finalidade de estadiamento do processo inflamatório, utilizando as amostras coletadas para a confecção de lâminas de citologia, podemos utilizar o LTB ou o LBA, porém existem diferenças nas populações celulares entre os segmentos das vias respiratórias ${ }^{2,51}$. O exame do LTB é útil para detectar inflamação das grandes vias respiratórias e para isolamento de microrganismos, já o LBA é útil para coleta de amostras de secreções em vias respiratórias mais profundas e é mais representativo das pequenas vias respiratórias e, em menor extensão, de secreções ou exsudatos alveolares e do parênquima pulmonar, dessa forma auxilia na detecção de doença pulmonar generalizada, mas não necessariamente na detecção de doença localizada ${ }^{2}$.

A ultrassonografia torácica possibilita a identificação de alterações subpleurais como abscessos, tumores, enfisemas, aderências e alterações pleurais, principalmente quando ocorre acúmulo de líquido na cavidade torácica. Cabe acrescentar que é cada vez mais comum a disponibilidade da utilização do aparelho de ultrassonografia nas propriedades especializadas como método de valor diagnóstico em doenças respiratórias de bezerros ${ }^{65-67}$.

A radiografia torácica de bezerros apresenta uma boa sensibilidade para a detecção de doenças respiratórias, entretanto não é uma técnica fácil de ser realizada à campo. Existem aparelhos portáteis que podem ser levados até as propriedades, porém não é corriqueiro para a bovinocultura. Em bezerros as radiografias podem ser realizadas em estação ou em decú- bito lateral, e o centro da imagem é fixado no centro do tórax entre o terceiro e quarto espaço intercostal. Pode fornecer dados da localização e extensão da pneumonia, além de permitir a avaliação da evolução e do curso da pneumonia ${ }^{68}$.

\section{ACHADOS DE NECROPSIA}

A morte de um animal não significa que o diagnóstico foi perdido, uma necropsia bem direcionada pode facilitar o entendimento da história natural da doença naquela população. Em surtos em que o diagnóstico é duvidoso, a alternativa para a realização de um diagnóstico da enfermidade é o exame necroscópico. Através da necropsia pode-se colher material para determinar o agente causal, identificar o grau e a extensão da lesão e avaliar a eficácia dos tratamentos prescritos. Com o material colhido durante o exame necroscópico podemos fazer cortes histológicos e pesquisar a presença de células infectadas por vírus através de anticorpos marcados, e ainda realizar o isolamento do agente em cultivo celular através de material macerado.

Observar as lesões também pode fornecer informações sobre a doença, macroscopicamente podemos observar consolidação pulmonar ou hepatização crânio-ventrais, coloração vermelho escura ou acinzentada, ao corte, a superfície tem aspecto úmido, podendo apresentar exsudato mucopurulento ou purulento ( $\mathrm{Fi}$ gura 2). Quando o exsudato for do tipo fibrinoso, a superfície pode estar ressecada. Em casos de lesão por VRSB, a consolidação pulmonar pode ser crânioventral ou intersticial dorso-caudal ou ambas. As lesões são bem delimitadas, devido ao padrão lobular bem evidenciado, e o pulmão afetado apresenta consistência firme e mais pesado ${ }^{13}$.

Microscopicamente pode-se observar edema, presença de neutrófilos, congestão, aumento de macrófagos alveolares, e nas lesões mais crônicas pode ser observado grande quantidade de macrófagos e proliferação de pneumócitos tipo II. 


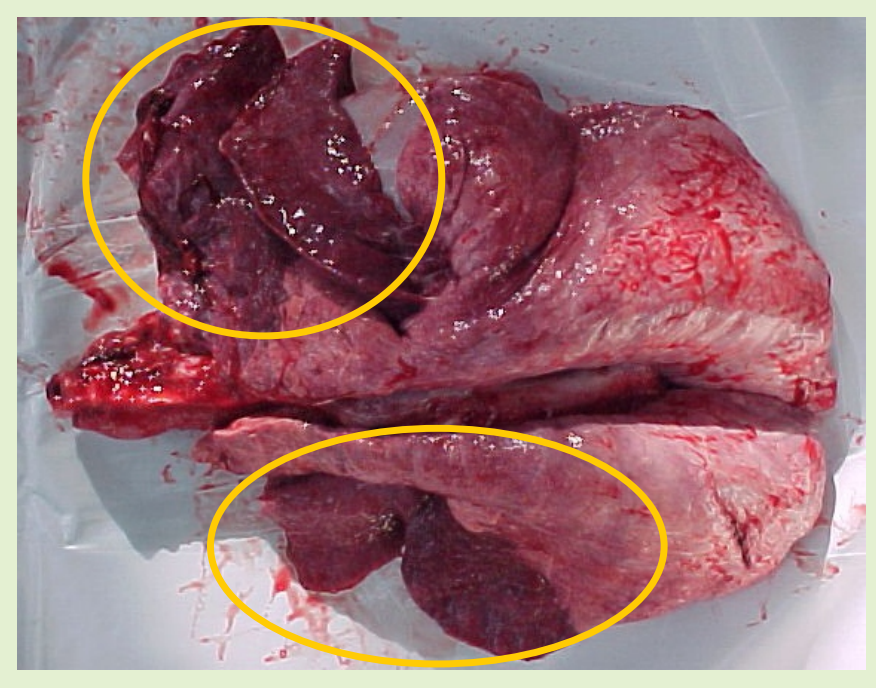

Figura 2: Pulmão de bezerro com broncopneumonia apresentando hepatização crânio-ventral de coloração vermelho escura (círculos amarelos).

\section{DIAGNÓSTICO DIFERENCIAL}

Devemos realizar o diagnóstico diferencial das broncopneumonias entre si (viral, bacteriana, mista); com as enfermidades de outros sistemas que possam causar dispneia como a insuficiência cardíaca congestiva, acidose ruminal, condições que cursam com hipertermia; com pleurite e pneumotórax e ainda com enfermidades do trato respiratório superior como as laringites e traqueítes e no caso de suspeita de dictiocaulose deve-se realizar exame coproparasitológico ${ }^{52}$.

Existe uma preocupação em realizar o diagnóstico diferencial, não somente para confirmar a doença, mas também para realizar um tratamento correto, pois sendo uma doença multifatorial, um diagnóstico diferencial rápido e eficiente pode auxiliar os veterinários para que o correto tratamento seja prontamente instituído ${ }^{69}$.

\section{TRATAMENTO}

Independentemente da fase em que o animal se encontra e do agente causal predominante, o tratamento deve ser iniciado pela retirada do animal doente do ambiente em que está e monitorar os demais contactantes. Este deve ser levado para um local seco, arejado, limpo e com alimentação adequada. $\mathrm{O}$ tratamento deve ser iniciado o mais rápido possível, pois se as lesões se tornarem muito avançadas, os agentes antimicrobianos dificilmente alcançarão as áreas de necrose e supuração e a resposta regenerativa não será capaz de devolver esse tecido ao parênquima pulmonar normal ${ }^{8}$.

A escolha do antimicrobiano dependerá do custo, disponibilidade, eficácia esperada com base na experiência anterior com antimicrobianos em uma área específica, facilidade de administração, frequência de administração necessária e concentrações de antimicrobianos que podem ser alcançadas nos tecidos pulmonares dos animais afetados ${ }^{2}$. Os antimicrobianos mais utilizados estão descritos no Quadro 3, com as doses e via de administração indicadas. Nesses casos de infecção bacteriana deve-se instaurar a terapia antimicrobiana para controlar ou interromper a replicação do patógeno $^{8,70,71}$.

A utilização de anti-inflamatórios também é válida em alguns casos. $\mathrm{O}$ uso de anti-inflamatórios não esteroidais (AINE) resulta na melhora dos sinais clínicos e na redução da consolidação pulmonar ${ }^{8,71}$. Segundo trabalho recente o uso de AINE por via intravenosa logo após o aparecimento dos sinais clínicos tornam as lesões pulmonares consistentemente menos severas do que em animais não tratados além de estabilizar os sinais clínicos, pois em animais não tratados ocorre o agravamento desses sinais ${ }^{72}$.

A terapia anti-inflamatória demonstrou ser benéfica em muitos estudos em casos de doença respiratória grave que se caracterizam por dispneia acentuada, febre e diminuição da ingestão de alimentos. Os efeitos melhor estabelecidos dos fármacos AINE em animais que sof rem de CDBR, são o declínio mais rápido da temperatura retal e o retorno mais rápido à ingestão de alimentos e água ${ }^{2}$, não apresentando influência direta no sistema imune do animal ${ }^{73}$, deve-se apenas tomar cuidado quando for administrado para animais 
Quadro 3 - Medicamentos indicados e doses para tratamento de broncopneumonia

\begin{tabular}{|c|c|c|c|}
\hline \multicolumn{2}{|c|}{ Classe } & Dose (via de administração) & Frequência \\
\hline \multicolumn{4}{|c|}{ ANTIBIÓTICOS } \\
\hline \multirow{2}{*}{ Enrofloxacina } & $10 \%$ & 2,5 a $5,0 \mathrm{mg} / \mathrm{kg}(\mathrm{IM})$ & A cada 24 horas, por 3 dias \\
\hline & LA & 7,5 a $12,5 \mathrm{mg} / \mathrm{kg}$ (SC ou IM) & Dose única \\
\hline \multirow{2}{*}{\multicolumn{2}{|c|}{ Florfenicol }} & 20 mg/kg (IM) & A cada 48 horas \\
\hline & & $40 \mathrm{mg} / \mathrm{kg}(\mathrm{SC})$ & Dose única \\
\hline \multicolumn{2}{|c|}{ Norfloxacina } & $5 \mathrm{mg} / \mathrm{kg}$ (IM ou SC) & A cada 24 horas, por 3 a 5 dias \\
\hline \multicolumn{2}{|c|}{ Oxitetraciclina Solução } & $10 \mathrm{mg} / \mathrm{kg}(\mathrm{IM})$ & A cada 12 horas, por 4 dias \\
\hline \multicolumn{2}{|c|}{ Sulfa + Trimetropima } & 15 a 60 mg/kg (IV) & A cada 24 horas, por 3 dias \\
\hline \multicolumn{2}{|c|}{ Tilmicosina } & $10 \mathrm{mg} / \mathrm{kg}(\mathrm{SC})$ & Dose única \\
\hline \multicolumn{2}{|c|}{ Tulatromicina } & $2,5 \mathrm{mg} / \mathrm{kg}(\mathrm{SC})$ & Dose única \\
\hline \multicolumn{4}{|c|}{ ANTIINFLAMATÓRIOS } \\
\hline \multicolumn{2}{|c|}{ Flunixin meglumine } & $\begin{array}{c}2,2 \mathrm{mg} / \mathrm{kg} \text { (dose de ataque) e } \\
1,1 \mathrm{mg} / \mathrm{kg} \text { (IM) }\end{array}$ & A cada 24 horas, por 3 dias \\
\hline \multicolumn{4}{|c|}{ BRONCODILATADORES } \\
\hline \multicolumn{2}{|c|}{ Clembuterol } & $0,8 \mu \mathrm{g} / \mathrm{kg}(\mathrm{VO})$ & A cada 24 horas \\
\hline \multicolumn{4}{|c|}{ EXPECTORANTES } \\
\hline \multicolumn{2}{|c|}{ lodeto de potássio } & 5 a 10 mg/kg (VO) & A cada 6 horas \\
\hline \multicolumn{2}{|c|}{ Bromexina } & 0,2 a $0,5 \mathrm{mg} / \mathrm{kg}$ (IM ou VO) & A cada 6 horas \\
\hline \multicolumn{4}{|c|}{ ANTIPIRÉTICO } \\
\hline \multicolumn{2}{|c|}{ Dipirona } & $50 \mathrm{mg} / \mathrm{kg}(\mathrm{IV})$ & Quando apresentar febre ( $\geq 39,4 \stackrel{\circ}{ } \mathrm{C})$ \\
\hline
\end{tabular}

Legenda:Intramuscular(IM), intravenosa (IV), subcutânea (SC) e via oral (VO)

desidratados, pois os AINE têm potencial nefrotóxico. Outro cuidado a ser tomado é com o uso prolongado dos AINE, pois podem causar úlceras de abomaso.

Para auxiliar as funções mecânicas do pulmão (funcionamento da musculatura lisa, permeabilidade dos capilares pulmonares e a depuração mucociliar) podemos administrar broncodilatadores, vasodilatodores e estimulantes da depuração mucociliar, pois diminuem o esforço respiratório e o risco de fadiga dos músculos respiratórios, melhorando o intercâmbio gasoso pulmonar. Expectorantes, como o iodeto de potássio e a bromexina, também podem ser usados nos casos em que o animal apresenta muita secreção em vias aéreas. Se o animal apresentar quadros de febre alta pode ser administrada dipirona por via intravenosa.

Em ambientes mais controlados podemos realizar inalação nos animais com maior dificuldade respiratória (Figura 3). A nebulização com soluções isotônicas como $\mathrm{NaCl}$ 0,9\% ou com água são potentes secretolíticos, auxiliando na eliminação do muco e 
melhorando a ventilação. Podemos ainda associar antibióticos, expectorantes e broncoespasmolíticos na nebulização, pois dessa forma atinge pontos mais profundos da árvore brônquica e apresenta rápida ação do medicamento. Devemos evitar soluções hipotônicas, como água destilada, pois causam broncoespasmo; e soluções hipertônicas que causam aumento da secreção brônquica.

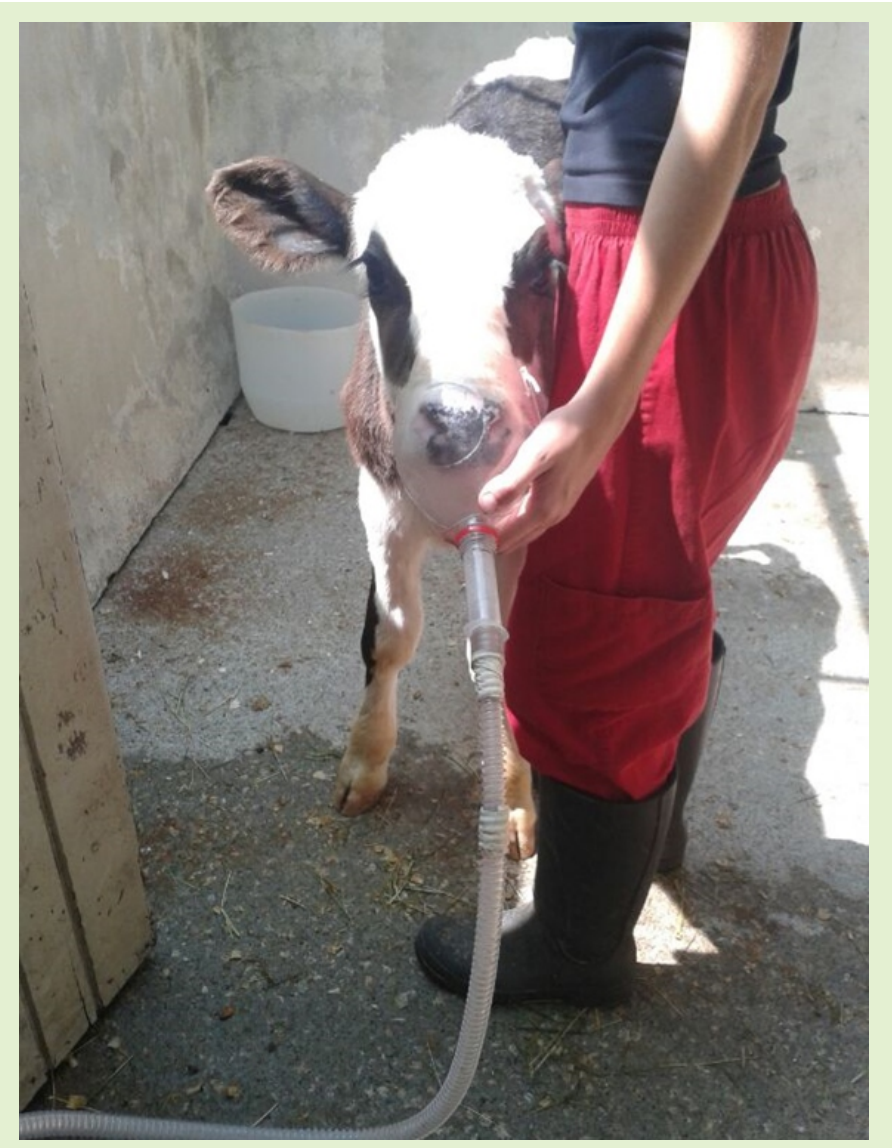

Figura 3: Nebulização em bezerro com doença respiratória.

\section{PROFILAXIA E CONTROLE}

O controle da doença respiratória requer um bom entendimento das formas de disseminação e da susceptibilidade dos animais. O CDRB pode ser prevenido pela eliminação ou modificação do maior número possível de fatores predisponentes. $\mathrm{O}$ controle começa pela mãe, oferecendo uma boa alimentação durante a gestação favorecendo o crescimento do feto e permi- tindo o nascimento de bezerros saudáveis ${ }^{74}$.

O local onde será a maternidade (baia ou piquete) deve receber cama limpa e seca e ser desinfetada após cada parto, buscando sempre manter a densidade populacional baixa. $\mathrm{O}$ trabalho de parto deve ser monitorado e, se necessário, pessoal qualificado deve intervir o mais rápido possível.

Após o parto os cuidados devem ser focados na bezerra, garantindo a transferência de imunidade passiva, realizando a desinfecção do umbigo e evitando a prática de manejos estressantes. Para tal, é ideal manter um bom banco de colostro e um correto fornecimento aos bezerros. Os bezerros precisam receber um volume de colostro correspondente a 10 a $12 \%$ de seu peso vivo, o mais rápido possível após o nascimento ${ }^{75}$. O umbigo deve ser curado logo após o nascimento com iodo a $10 \%$, somente no primeiro dia de vida, iodo a $5 \%$ a partir do segundo dia de vida, duas vezes ao dia, durante três dias, seguido de uma vez ao dia, até a secagem completa $^{76}$.

Manter os animais em locais limpos e que ofereçam o menor contato possível com patógenos além de não sofrer mudanças bruscas de temperatura, evitar realizar práticas de manejo estressantes em um curto período, especialmente durante períodos de variações climáticas intensas. Essas instalações devem estar em uma área suficientemente distante daquelas utilizadas por animais adultos, e possuir ventilação independente, não devendo receber o ar que passou pelas instalações de animais adultos ${ }^{77}$.

A vacinação para prevenção de doença respiratória se mostrou controversa. Vacinas virais multivalentes contra Herpesvírus Bovino 1 (HVB-1), VBVD tipos 1 e 2, VSRB e VPI-3 estão comercialmente disponíveis inativadas e em formas ativas (vírus vivo modificado). Além disso, formulações de bacterina e/ou leucotoxoide estão disponíveis contra $M$. haemolytica (incluindo sua leucotoxina), P. multocida e $H$. somni. Todas essas vacinas contra agentes causadores do $\mathrm{CDRB}$ reconhecidos requerem tempos variados para 
estimular uma resposta imune ativa que resulte em proteção. Nenhuma das vacinas fornece imunidade protetora total em todos os animais e em todas as populações, por isso o momento da administração é crítico para a eficácia e eficiência da vacina ${ }^{78}$.

Numerosos estudos demonstraram os efeitos inibitórios da imunidade passiva nas respostas imunes induzidas por vacinas e proteção completa contra vírus respiratórios após a administração parenteral de vacinas contra CDRB em bezerros leiteiros para a prevenção de doenças respiratórias. Há uma falta de conexão entre os resultados de estudos de eficácia da vacina de CDRB que ocorrem naturalmente e os induzidos experimentalmente. Existem evidências limitadas de qualidade moderada de que a vacinação de bezerros leiteiros jovens com vacinas parenterais ou intranasais de vírus vivo modificado é ineficaz para reduzir a doença respiratória de ocorrência natural. Em contraste, há fortes evidências de que a vacinação de bezerros leiteiros jovens com vacinas parenterais ou intranasais de vírus vivo modificado é eficaz ao fornecer proteção clínica contra DRB após desafio experimental com vírus respiratórios ${ }^{79}$.

Apesar de poucas evidências e muitas controversas, as vacinas intranasais vem sendo utilizadas, pois conferem imunidade local aumentando a resposta local de $\operatorname{Ig} \mathrm{A}^{80}$. O melhor momento para vacinar bovinos contra os agentes causadores de CDRB é quando eles estão em um estado de homeostase imunológica, livre de infecção aguda e pelo menos várias semanas antes que o desafio natural seja esperado. Simplificando, a vacinação deve ocorrer antes do desmame e de outros manejos estressantes como a mochação e a troca de ambiente $^{78}$.

Ainda que a eficácia da vacinação seja dependente de fatores coletivos e individuais, a adoção desta prática e de estratégias de manejo adequadas, são os fundamentos para o sucesso no controle e profilaxia desse complexo respiratório, além de se utilizar a metafilaxia como forma de controle de surtos, embora haja grande preocupação com a resistência aos antibacterianos. Há também métodos alternativos para reduzir o impacto causado na bovinocultura. Alguns destes métodos baseiam-se em mecanismos de defesa do sistema imune inato, em que a imunomodulação e o "treinamento" do sistema inato são alternativas futuras aos antibacterianos ${ }^{81}$.

O sistema imunológico inato pode ser preparado, pela exposição a determinados microrganismos ou moléculas, isso pode resultar em um estado aprimorado de responsividade a estímulos secundários. Este estado aprimorado de responsividade, denominado imunidade treinada, é induzido principalmente por monócitos, macrófagos e células NK, o que permite maior expressão de citocinas e maior capacidade de prevenir infecções. Este campo ainda necessita de mais estudos, visto que os fatores que influenciam devem ser elucidados em nível dos tipos celulares envolvidos, no desenvolvimento das ciências ômicas para identificação de subpopulações celulares, além de compreensão do efeito desta imunidade sobre a doença. Mas com esse avanço podem ser aplicados vacinas de nova geração que combinem memória imune adaptativa e inata, uso de indutores de imunidade treinada para o tratamento de paralisia imune e modulação das consequências potencialmente deletérias da imunidade treinada em doenças auto inflamatórias, para que então a imunidade treinada alcance o potencial terapêutico ${ }^{81}$.

Além disso, o sistema imune inato dos bovinos produz peptídeos que são antimicrobianos e têm sido estudados para o uso como alternativa terapêutica aos antibacterianos. NK-lisina é um peptídeo antimicrobiano que foi descrito nos grânulos de células T citotóxicas e células NK em humanos, em suínos e bovinos. Embora humanos e suínos tenham apenas um gene NK-lisina, os bovinos possuem quatro genes NK-lisina funcionais: NK1, NK2A, NK2B e NK2C ${ }^{82}$. A expressão do gene NK-lisina é regulada positivamente nos pulmões de animais infectados com Mycoplasma bovis, M. haemolytica, $P$. multocida, e in vitro, a NK-lisina tem 
atividades antimicrobianas ${ }^{82,83}$.

Para auxiliar na correta prevenção devemos incluir o protocolo de vacinação das mães no período pré-parto, para reforçar as concentrações de imunoglobulinas contra patógenos respiratórios no colostro, e secundariamente no soro do bezerro. Portanto, um correto manejo sanitárió pode prevenir doenças do complexo respiratório. Mães saudáveis implicam em bezerros saudáveis.

\section{CONSIDERAÇÕES FINAIS}

Considerando a alta incidência da doença nos rebanhos leiteiros e o prejuízo causado em decorrência das perdas animais, gastos com tratamento e baixo desenvolvimento das bezerras, os fatores preventivos são fundamentais para o controle das doenças respiratórias. Portanto investir no manejo sanitário das mães, nos cuidados perinatais, nas instalações e alimentação das bezerras é de suma importância. Independente desse manejo, caso a doença se instale na propriedade, realizar o diagnóstico precoce e a pronta instituição da terapia é essencial para diminuir mortalidade, evolução e disseminação da doença, e a possibilidade de sequelas respiratórias nos animais acometidos. 


\section{PNEUMONIAS VERMINÓTICAS}

\section{Etiologia}

Causada pelo nematódeo Dictyocaulus viviparus, único helminto que na forma adulta infecta o pulmão de bovinos.

\section{Epidemiologia}

- Ocorre principalmente em regiões mais frias e úmidas (meses mais frios do ano), pois as larvas são resistentes ao frio e sensíveis ao calor.

- No Brasil há mais frequência em regiões serranas e vales próximos a serras.

- Bezerros jovens, até o primeiro ano de vida, são mais susceptíveis, geralmente acometem vários animais da mesma idade, pois se encontram no mesmo lote ou piquete.

- Os animais adultos, em locais com a presença do agente, conseguem controlar a infestação, e com pouca frequência apresentam manifestações clínicas, tornando-se portadores e fonte de infecção. Após contato com o $D$. viviparus os animais adquirem imunidade sólida contra o agente.

Manifestações clínicas e consequências

- Perda de peso (anorexia), produção reduzida de leite, acompanhadas de diferentes infecções nos bovinos, ovinos e caprinos.

- Infecções subclínicas patentes podem ocorrer em todas as espécies.

- Taquipneia e tosse, secreção nasal. Inicialmente respiração rápida e superficial, acompanhada de tosse exacerbada pelo exercício.

- Dispneia, animais infectados maciçamente permanecem com suas cabeças estendidas para frente, com a boca aberta e com salivação.

- Ruídos pulmonares proeminentes na bifurcação brônquica.

- No gado leiteiro adulto, queda severa na produção leiteira e ruídos pulmonares anormais acima dos lobos caudais do pulmão.

- Obstrução das vias aéreas e colapso dos alvéolos distais ao bloqueio (por um infiltrado de eosinófilos em resposta ao desenvolvimento das larvas).

- Pneumonia crônica, não supurativa, eosinofílica e granulomatosa (resposta aos ovos e às larvas de primeiro estágio que são aspiradas no interior de alvéolos e bronquíolos).

- Enfisema intersticial, edema pulmonar e infecção secundária são complicações que aumentam as probabilidades de um resultado fatal.

\section{Diagnóstico}

- Avaliação dos sinais clínicos, epidemiologia, necrópsia.

- Presença da larva de primeiro estágio nas fezes e necropsia dos animais do mesmo grupo ou do mesmo rebanho.

- Broncoscopia e radiografia podem ser úteis em alguns casos.

- As larvas não são encontradas nas fezes de animais nos períodos pré ou pós-patente e, usualmente, também não o são no fenômeno de reinfecção.

- Para detectar larvas: método de Baermann, em infecções maciças as larvas podem estar presentes dentro de trinta minutos.

\section{Tratamento}

- Levamisol, os benzimidazóis (fenbendazol, oxifendazol e albendazol), assim como a ivermectina são frequentemente usados em bovinos, e são efetivos contra todos os estágios de Dictyocaulus. Estas drogas são também efetivas contra vermes pulmonares em ovinos e caprinos.

- Animais no pasto devem ser confinados.

- Terapia de suporte pode ser necessária para complicações que podem aparecer em todas as espécies.

\section{Profilaxia e Controle}

- Não permitir que bezerros pastejem com outros animais.

- Impedir seu acesso a pastos com história de infecção recente por vermes pulmonares.

- Combinação de uma prática regular de pastoreio com antihelmínticos estratégicos.

- A vacinação contra os parasitas pulmonares que infestam os bovinos é praticada em larga escala no noroeste da Europa.

- A vacina é constituída de larvas infectantes atenuadas, irradiadas pelos raios- $\mathrm{X}$, administradas por via oral em duas doses com intervalo de quatro semanas.

\section{Achados de Necrópsia}

- Apresenta áreas de consolidação pulmonar, geralmente em porções caudais, principalmente em lobos diafragmáticos.

- A lesão primária causada pelos parasitas é caracterizada por uma bronquite crônica com broncoestenose e enfisema alveolar.

- A presença do parasita causa obstrução parcial ou expiratória dos brônquios, há também a presença de muco e exsudato. 

obrigação do teste e determinaram que as vacas com reação positiva fossem marcadas a ferro com a letra ' $T$ ', retiradas dos estábulos e encaminhadas para abate no matadouro

INTRODUÇÃO

A tuberculose bovina é uma doença de caráter crônico, de notificação obrigatória, que infecta ruminantes, suínos, aves, animais silvestres e humanos ${ }^{84}$. É causada pelo Mycobacterium bovis e Mycobacterium avium acarretando perdas econômicas significativas, além de ser uma das mais importantes zoonoses de relevância para a saúde pública, por isso o Ministério da Agricultura, Pecuária e Abastecimento (MAPA), por meio de programas de controle e erradicação como o Programa Nacional de Controle e Erradicação de Brucelose e Tuberculose (PNCEBT), lança mão de ações visando reduzir a prevalência deste problema em todo o país.

No início do século passado, a atenção dada à tuberculose bovina era praticamente nula, pois não se acreditava que a doença dos animais pudesse ser transmitida aos humanos, principalmente via leite, fazendo com que produtores relutassem em realizar o teste diagnóstico em seus animais, e àqueles que o faziam, continuavam comercializando o leite e muitas vezes o próprio animal para outras propriedades, perpetuando a disseminação da doença pelo país, o que fez grandes sanitaristas da época emplacarem uma dura batalha para combater a doença ${ }^{85}$.

"Em 1902 Clemente Ferreira descreveu a adoção dos primeiros dispositivos legais de âmbito municipal instituindo municipal. Determinavam ainda a realização de exames necroscópicos comprobatórios da infecção, para fins de registro e contraprova legal."(Antunes et al.85 p.611).

De maneira geral, a tuberculose bovina não era uma doença que chamasse atenção inicial de produtores, por ter curso crônico, as manifestações demoram a aparecer, então a importância econômica atribuída à doença está baseada nas perdas diretas resultantes da morte de animais, da queda no ganho de peso e diminuição da produção de leite, do descarte precoce e eliminação de animais de alto valor zootécnico e condenação de carcaças no abate. Estima-se que os animais infectados percam de $10 \%$ a $25 \%$ de sua eficiência produtiva. Existe ainda a perda de prestígio e credibilidade da propriedade onde a doença é diagnosticada ${ }^{86}$.

\section{DEFINIÇÃO}

Doença infectocontagiosa causada por uma bactéria (M. bovis) estreitamente relacionada às formas humana e aviária da tuberculose (zoonose). Apresenta todos os mamíferos como susceptíveis. De evolução crônica, caracterizada pelo desenvolvimento progressivo de lesões nodulares denominadas tubérculos ou granulomas, que podem localizar-se em qualquer órgão ou tecido $^{13}$.

O Gênero Mycobacterium contém mais de 127 espécies, entre elas destacam-se as incluídas no complexo Mycobacterium tuberculosis (M. tuberculosis, M.bovis e 
M. africanum). O termo tuberculose deve ser reservado para designar a doença causada pelo $M$. tuberculosas, $M$. bovis e $M$. avium, agentes etiológicos da tuberculose humana, bovina e aviária, respectivamente. Doenças causadas por outras micobactérias são denominadas micobacterioses $^{87}$.

\section{ETIOLOGIA}

A tuberculose é causada por um bacilo álcoolácido resistente, ou seja, que quando corado pela fucsina aquecida, não se descora pelo álcool clorídrico (coloração de Ziehl-Neelsen). É uma bactéria de crescimento lento, aeróbica, imóvel, não encapsulada e não esporulada, que pertence à Ordem Actinomycetales, Família Mycobacteriaceae e ao gênero Mycobacterium. São bastonetes curtos, que apresentam aspecto granular quando corados e medem de 0,5 a 7,0 $\mu \mathrm{m}$ de comprimento por $0,3 \mu \mathrm{m}$ largura.

Pode sobreviver fora do hospedeiro por longos períodos, em instalações, fezes, solo e pastagens por até dois anos, na água por aproximadamente um ano e em carcaças por até dez meses. Sensível ao fenol, formol, cresol, hipoclorito de cálcio 5\% e hipoclorito de sódio $5 \%$ e calor (autoclave $120^{\circ} \mathrm{C}$ por vinte minutos, pasteurização e exposição à luz solar) ${ }^{86}$.

\section{EPIDEMIOLOGIA}

A via de infecção é geralmente broncogênica, pois a principal forma de transmissão é por aerossóis. $\mathrm{O}$ processo se inicia na junção bronquíolo-alveolar e se estende para o interstício, formando pequenos nódulos granulomatosos com aspecto caseoso. Mas pode ocorrer transmissão através de leite contaminado, água e alimentos contaminados pela via digestória. As principais fontes de infecção são os animais doentes e portadores inaparentes, pois podem eliminar o agente por meio de fezes, urina, sêmen, leite, colostro, gotículas e secreções respiratórias $^{13}$.

A principal forma de introdução da tuberculose em um rebanho é a aquisição de animais infectados. Eventualmente, o homem com tuberculose causada pelo $M$. bovis pode ser fonte de infecção para os rebanhos $^{88}$.

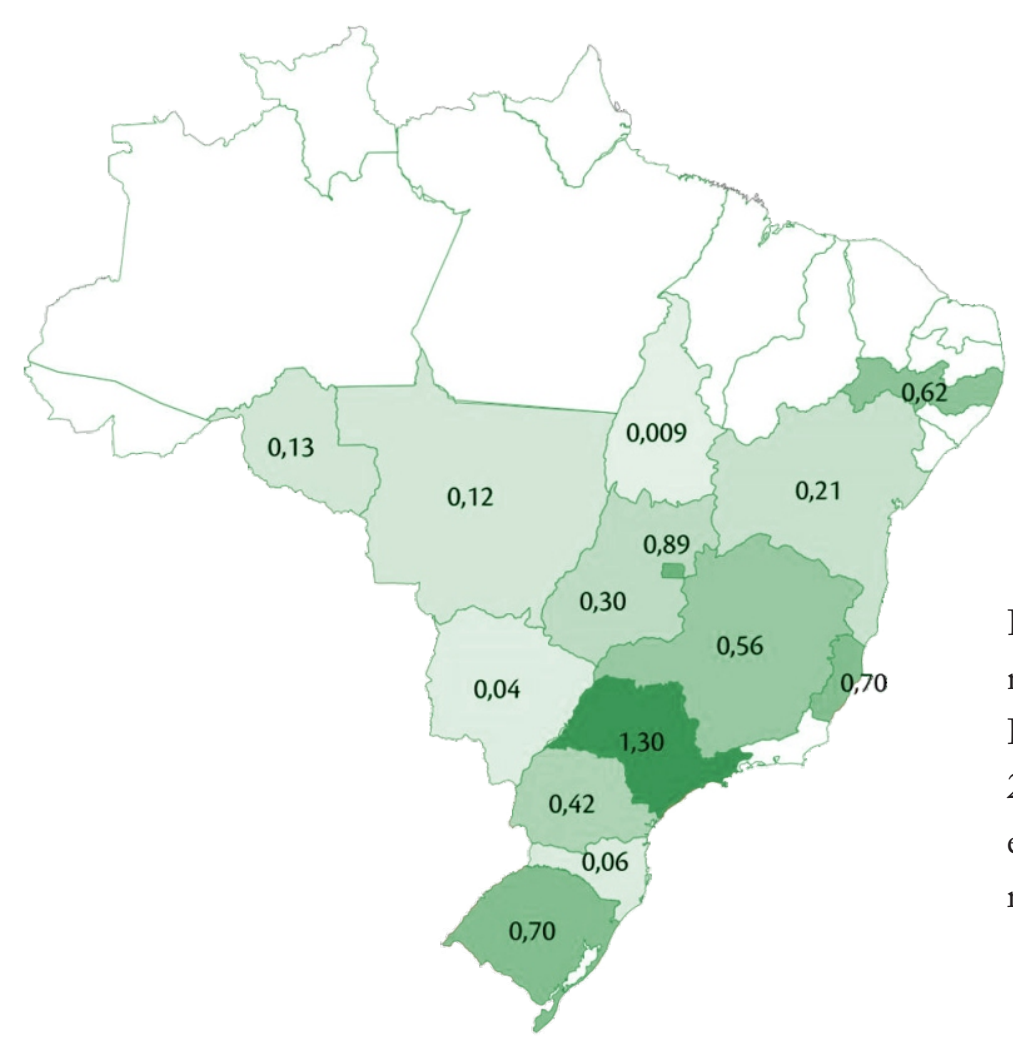

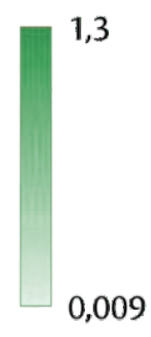

Figura 4: Prevalência de casos de tuberculose bovina nos estados da BA, DF, ES, GO, MG, MS, MT, PE, $\mathrm{PR}, \mathrm{RO}, \mathrm{RS}, \mathrm{SC}, \mathrm{SP}$ e TO, realizados entre os anos de 2003 e 2018. Nos demais estados os inquéritos estão em andamento ( $\mathrm{AC}, \mathrm{PA}$ e $\mathrm{SE}$ ) ou não foram realizados. ${ }^{89}$ 


\section{PATOGENIA}

Podemos dividir a patogenia da tuberculose em fases (Figura 5).

$\mathrm{Na}$ fase inicial, a tuberculose pode se resolver, caso o animal tenha boas condições imunológicas para debelar a infecção. Entretanto, quando instalado o $M$. bovis pode ser disseminado por via linfática, com acometimento de linfonodos mediastinais; o exsudato produzido pela presença do agente é rico em bacilos, e ao ser expelido por meio de tosse pelo animal, pode ser deglutido podendo causar tuberculose digestiva, uma vez que bovinos ingerem grande parte do exsudato das vias respiratórias; e por fim a via hematógena, quando nódulos tuberculosos rompem vasos sanguíneos e liberam êmbolos sépticos na circulação, podendo afetar qualquer órgão e resultando em quadro de tuberculose miliar .

A generalização da infecção pode ocorrer via disseminação linfática ou sanguínea para os demais linfonodos, úbere, fígado, baço, ossos, rins, sistema nervoso central; e a forma miliar, que apresenta disseminação abrupta e maciça. Ocorre geralmente em imunode- primidos sendo fatal. $\mathrm{O} M$. bovis consegue persistir no organismo, pois consegue se multiplicar dentro dos macrófagos. A infecção se propaga nos animais independentemente do sexo, da raça ou da idade ${ }^{90}$.

\section{MANIFESTAÇÕES CLÍNICAS}

É uma doença de ocorrência mundial e no Brasil a doença é endêmica. A forma mais frequente é a pulmonar, que é de evolução lenta e o animal pode apresentar tosse, corrimento nasal, estertores pulmonares, emagrecimento crônico progressivo, hiperplasia de linfonodos superficiais e/ou profundos e dispneia. Pode ainda apresentar-se na forma intestinal, cutânea e genital apresentando mastite, infertilidade, entre outros, dependendo do local das lesões ${ }^{2}$.

\section{DIAGNÓSTICO}

O diagnóstico da tuberculose bovina pode ser efetuado por métodos diretos e indiretos. Os diretos envolvem a detecção e identificação do agente etiológico no material biológico. Os indiretos pesquisam uma

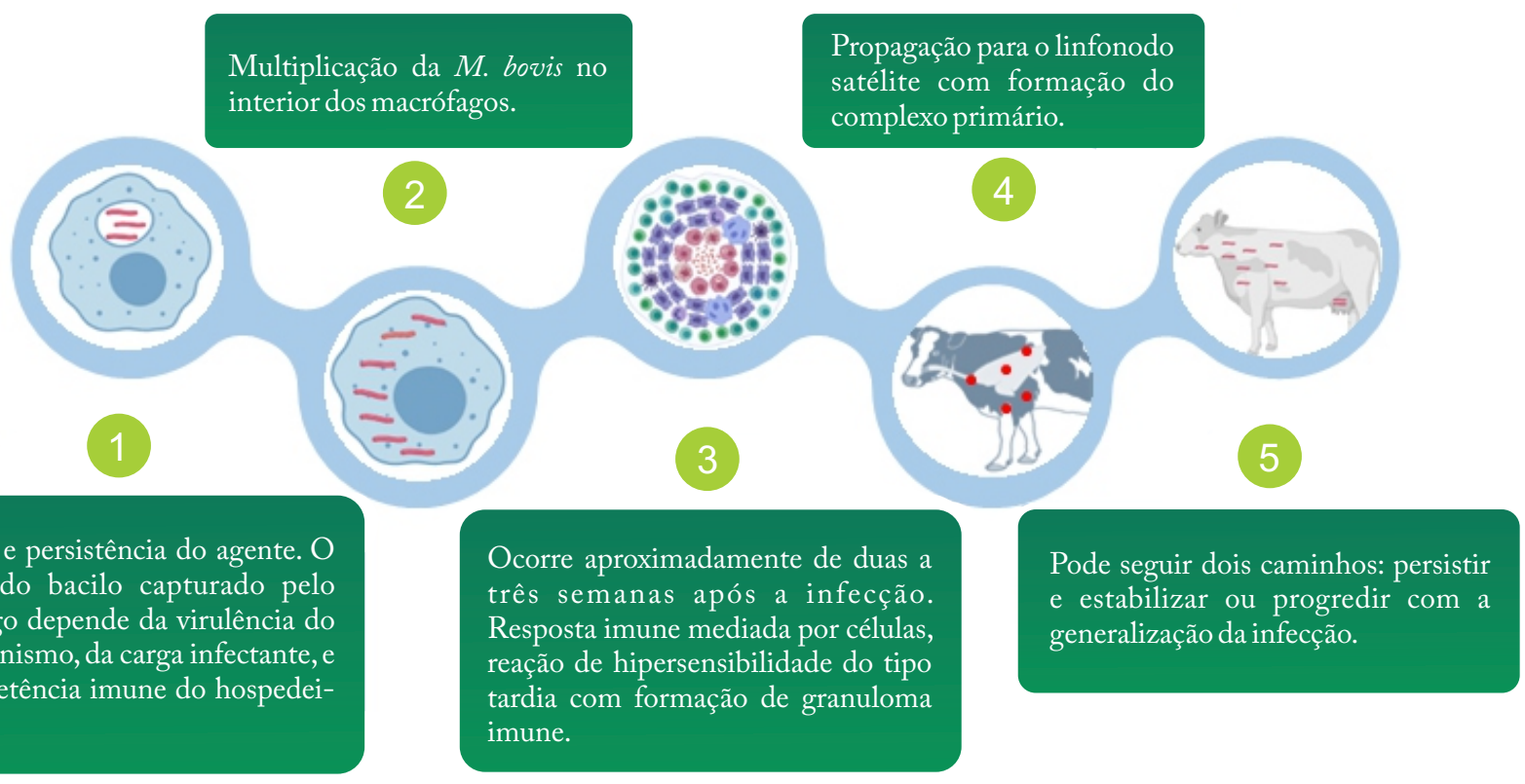

Figura 5. Cinco fases da patogenia da tuberculose bovina.

Infecção e persistência do agente. $\mathrm{O}$ destino do bacilo capturado pelo macrófago depende da virulência do microrganismo, da carga infectante, $\mathrm{e}$ da competência imune do hospede ro. 
resposta imunológica do hospedeiro ao agente etiológico. A reação tuberculínica, a bacteriologia e a histopatologia são os métodos mais utilizados para o diagnóstico da tuberculose ${ }^{86}$.

No Brasil, segundo o PNCEBT do MAPA, os testes de rotina recomendados para o diagnóstico de tuberculose bovina são o teste cervical simples (TCC), o teste da prega caudal (TPC) e o teste cervical comparativo (TCC), sendo que o último também é utilizado como teste confirmatório ${ }^{86}$. A intensidade da reação à prova não indica a gravidade da doença, pelo contrário indica alta imunogenicidade.

O TCC consiste na medição da espessura da pele da região cervical antes da aplicação dos antígenos, em seguida deve-se realizar a aplicação intradérmica de $0,1 \mathrm{~mL}$ de derivado proteico purificado bovino $(\mathrm{PPDb})$ e $0,1 \mathrm{~mL}$ de derivado proteico purificado aviário (PPDa), com distância de 15 a $20 \mathrm{~cm}$ entre as duas inoculações. O PPDa deve ser injetado cranialmente e o PPDb injetado no terço médio da região cervical (caudalmente em relação ao PPDa). As leituras devem ser feitas após 72 horas da inoculação com o auxílio de um cutímetro, avaliando-se a reação de hipersensibilidade tardia no local da inoculação. $\mathrm{O}$ animal será considerado positivo quando a reação ao PPDb foi superior a 4,0 $\mathrm{mm}$ em comparação com a reação ao $\mathrm{PPDa}$ (Quadro 4). Em cumprimento às instruções do PNCEBT, os testes devem ser realizados somente por médicos veterinários habilitados pelo MAPA e as notificações dos animais positivos devem ser encaminhadas à Defesa Agropecuária do local ${ }^{86}$.

Entretanto, o interesse científico em tuberculose nos últimos anos tem levado à necessidade de desenvolver e melhorar os métodos de diagnóstico, prevenção, controle e erradicação da doença.

No entanto alguns trabalhos indicam que em casos de infecção recente, o TCC pode causar resultado falso-negativo, o que poderia perpetuar a doença no rebanho, então o diagnóstico deveria ser realizado com o auxílio de outras técnicas concomitantes como a cul- tura e identificação do agente e o PCR de tecido ${ }^{91}$, entretanto essas técnicas só podem ser realizadas post mortem com a coleta de material em abatedouros.

Para tentar sanar esse viés, pesquisadores avaliaram outras alternativas para diagnóstico in vivo, como PCR de suabe nasal, porém a resposta não foi satisfatória, sendo o TCC mais sensível ${ }^{92}$.

Quadro 4. Interpretação do teste cervical comparativo (TCC) em bovinos ${ }^{86}$. $\triangle \mathrm{B}-\triangle \mathrm{A}(\mathrm{MM})$

$\Delta \mathrm{B}<2,0$

$\Delta \mathrm{B}<\Delta \mathrm{A}$

$\Delta \mathrm{B} \geq \Delta \mathrm{A}$

$\Delta \mathrm{B}>\Delta \mathrm{A}$

$\Delta \mathrm{B}>\Delta \mathrm{A}$
$<0$

0,0 a 1,9

2,0 a 3,9

$\geq 4,0$
Interpretação

Negativo

Negativo

Negativo

Inconclusivo

Positivo
O diagnóstico definitivo é realizado mediante o isolamento e a identificação do agente. Amostras frescas podem ser fixadas em lâmina e coradas pelo método de Ziehl-Neelsen para a pesquisa de bacilos álcool ácido resistentes (BAAR), porém, a sensibilidade do método é baixa, e um resultado positivo sugere fortemente tratar-se de micobactéria, mas não informa a espécie. $\mathrm{O}$ isolamento do agente em culturas bacterianas realizado em meios seletivos para micobactérias (Löwenstein-Jensen e Stonenbrink-Lesslie) permite identificar o agente, porém são extremamente demorados (60 a 90 dias) ${ }^{86}$. Porém, esses testes somente são realizados em casos confirmatórios em que TCC foi positivo e o animal não apresentava lesões visíveis, por exemplo.

\section{ACHADOS DE NECROPSIA}

Não se aconselha fazer necropsia, pois são agentes zoonóticos. $\mathrm{Na}$ eventualidade de realização de necropsia, é necessário usar o equipamento de proteção 

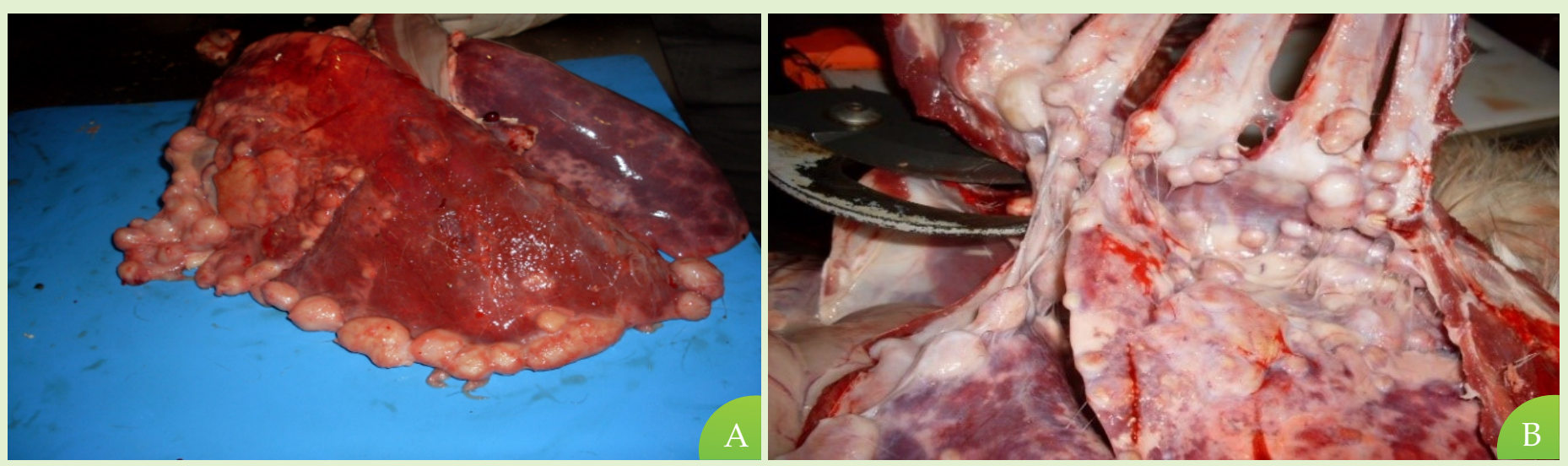

Figura 6: Pulmão de ruminante com lesões de Tuberculose. (A) Pulmão com nódulos e (B) nódulos em gradil costal e pleura e aderência no pulmão (Fonte:Batista,2008).

individual e descontaminar todos os materiais utilizados. Cuidado devem ser tomados ao manipular materiais infectados, ou potencialmente infectados, com $M$. bovis, pois é uma potencial forma de transmissão de tuberculose ao ser humano. A necropsia é somente indicada quando necessário coletar amostras para o cultivo bacteriológico ${ }^{86}$.

Macroscopicamente, observam-se nódulos de tamanhos variados por todo o parênquima pulmonar e linfonodos mediastinais, e eventualmente outros órgãos. Em estágios mais avançados pode ocorrer calcificação nas porções centrais dos nódulos ${ }^{13}$ (Figura 6).

\section{TRATAMENTO}

Animais positivos ao TCC devem ser destinados ao abate sanitário em locais com serviço de inspeção de carcaças e deve ser acompanhado pelo serviço oficial de defesa sanitária animal. Não existe tratamento possível.

\section{PROFILAXIA E CONTROLE}

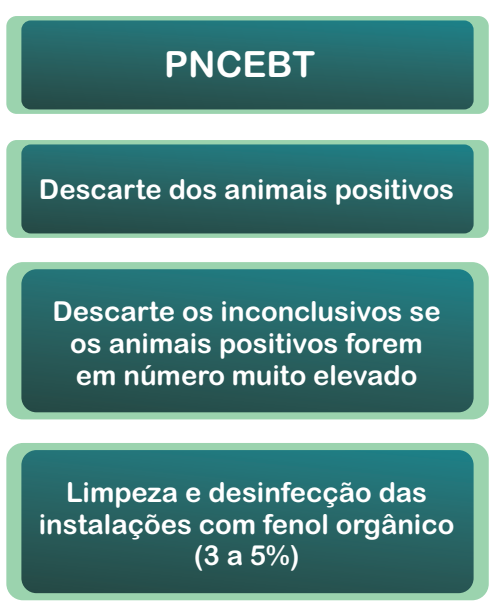

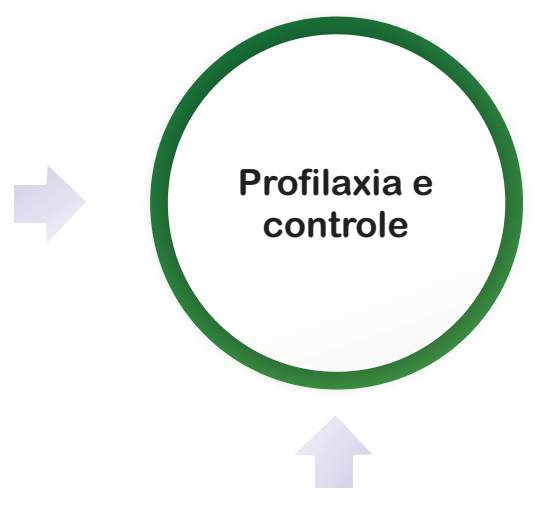

Instituição de quarentena
No prazo de noventa dias realizar teste de tuberculinização em todos os animais do rebanho acima de dois meses de idade

Passar a realizar testes de tuberculinização a cada três ou quatro meses até que dois testes consecutivos não apontem mais a ocorrência de animais positivos

A partir dai realizar testes de tuberculinização semestrais conforme recomendação de leite

Após cada teste com detecção de animais positivos realizar nova desinfecção geral de instalações

Figura 7.Profilaxia e controle da tuberculose bovina segundo o PNCEBT. 
Quadro 5:Produtos para desinfecção de instalações e utensílios em casos de tuberculose bovina ${ }^{86}$.

\begin{tabular}{|c|c|c|}
\hline Desinfetantes & Temperatura de uso & Indicação \\
\hline Cal (Hidróxido de cálcio 20\%) & Ambiente & Instalações e solo \\
\hline Cresóis 5\% & Ambiente & Instalações \\
\hline Fenol 5\% & $37 \stackrel{\circ}{C}$ & Instalações \\
\hline Formol 7,5\% (三 3\% de formaldeído) & Ambiente & Instalações, utensílios e roupas \\
\hline Hipoclorito de cálcio 5\% & Ambiente & Instalações e utensílios \\
\hline Hipoclorito de sódio 5\% & Ambiente & Instalações e utensílios \\
\hline Soda caustica $2 \%$ a $3 \%$ & $60 \stackrel{\circ}{C}$ & Instalações e utensílios \\
\hline
\end{tabular}

Tempo de exposição para ação dos desinfetantes de três horas. Fonte: Adaptado de Russel et al. ${ }^{93}$.

\section{CONSIDERAÇÕES FINAIS}

Apesar de todos os esforços para controlar a tuberculose bovina, ainda temos um longo caminho a ser percorrido para controlar a doença no nosso país. A tuberculose apresenta graves implicações de saúde púbica e econômica para as indústrias agrícolas. Programas de erradicação baseados em testes de tuberculina e subsequente abate de animais positivos têm sido bem-sucedidos em muitos países desenvolvidos. É preciso maior vigilância e adesão de produtores, médicos veterinários e autoridades para que possamos erradicar essa doença.

Considerada doença ocupacional que atinge principalmente tratadores, ordenhadores, açougueiros, magarefes e veterinários, mas atinge também o consumidor final, que muitas vezes se alimenta de produtos de origem bovina sem adequada inspeção, com queijos produzidos com leite cru, ou o consumo de carne provinda de locais sem fiscalização, apesar de parecer absurda essa afirmação, ainda é a realidade de boa parte da nossa população.

Outra grande preocupação é em relação ao consumo de produtos de origem de pequenos ruminantes, uma vez que esses animais são acometidos pela doença, são potenciais transmissores e não existe legislação que respalde o exame e o abate, assim como para bovinos e bubalinos.

$\mathrm{O}$ avanço no controle e erradicação da doença foi exponencial nos últimos anos, mas a vigilância e os esforços não podem parar.

\section{MATERIAL SUPLEMENTAR}

\section{Técnica de endoscopia em bezerro.}

\section{REFERÊNCIAS}

1. IBGE. Instituto Brasileiro de Geografia e Estatística. Indicadores do IBGE: estatística da produção pecuária. 2019. Brasília,p.80,2019. 
piratório. In: Clínica Veterinária - Um Tratado de Doenças dos Bovinos, Ovinos, Suínos e Caprinos. 11aed. Rio de Janeiro: Grupo GEN,2020.p.874-1126.

3. MACHADO NETO, R. et al. Levantamento do manejo de bovinos leiteiros recém-nascidos: desempenho e aquisição de proteção passiva. Revista Brasileira de Zootecnia, v.33, n.6, supl.3, p.2323-2329, 2004.

4. JARAMILLO-ARANGO, C. et al. Mannheimiosis bovina: etiología, prevención y control. Veterinaria México,v.40,n.3,p.293-314,2009.

\section{ZECCHINON, L. et al. How Mannheimia hae-} molytica defeats host defence through a kiss of death mechanism. Veterinary Research, v.36, n.2, p.133-156, 2005.

6. BENESI, F.J. Síndrome asfixia neonatal dos bezerros. Arquivos da Escola de Medicina Veterinária da Universidade Federal da Bahia,v.16, n.1, p.38-48,1993.

7. RABELO, S.S.A. et al. Sazonalidade da broncopneumonia em bezerros da microrregião de Garanhuns, Pernambuco (1983-1991). Arquivos Brasileiro de Medicina Veterinária e Zootecnia,v.48, n.1,p.19-26,1996.

8. AMES, T.R. et al. As Broncopneumonias (Complexo de Doenças Respiratórias de Bovinos, Ovinos e Caprinos). In: SMITH, B.P Medicina Interna de Grandes Animais. 3aed. São Paulo: Manole, 2006, p.511-570.

9. LEKEUX, P.A therapeutic strategy for treatment of the Bovine Respiratory Disease Complex: the rationale for the combination of a nonsteroidal antiinflammatory drug with an antibiotic. Cattle Practice, v.15, n.2,p.115-119, 2007.

10. ACKERMANN, M.R. et al. Innate immunology of bovine respiratory disease. Veterinary Clinics of North America: Food Animal Practice, v.26, n.2, p.215-28, 2010.

11. CASWELL, J.L. Failure of respiratory defenses in the pathogenesis of bacterial pneumonia of cattle. Veterinary Pathology, v.51,n.2,p.393-409,2014.

12. GONÇALVES, R.C. et al. Aspectos clínicos e epidemiológicos da broncopneumonia dos bezerros em Botucatu, SP. Revista Brasileira de Ciência Veterinária, v.7,n.3,p.144-147,2000.

13. SANTOS, R.L.; GUEDES, R.M.C. Sistema Respiratório.In: SANTOS R.L.; ALESSI,A.C.Patologia Veterinária.2aed. Rio de Janeiro: Roca,2016.p.1-47.

14. GRIFFIN, D. et al. Bacterial pathogens of the Bovine Respiratory Disease Complex. Veterinary Clinics of North America: Food Animal Practice, v.26, n.2, p.38194,2010.

15. MALAZDREWICH, C. et al. Pulmonary expression of tumor necrosis factor alpha, interleukin-1 beta, and interleukin- 8 in the acute phase of bovine pneumonic pasteurellosis. Veterinary Pathology, v.38, n.3, p.297-310,2001.

16. KATSUDA, K. et al. Serotyping of Mannheimia haemolytica isolates from bovine pneumonia: 19872006. Veterinary Journal,v.178, n.1,p.146-148, 2008.

17. SINGH, K. et al. Mannheimia haemolytica: bacterial-host interactions in bovine pneumonia. Veterinary Pathology,v.48, n.2, p.338-48, 2011.

18. SATHIAMOORTHY, S. et al. In vivo gene expression in Mannheimia haemolytica A1 during a time-course trial in the bovine host. Veterinary Microbiology,v.158,n.1-2,p.163-171,2012. 
19. AULIK, N. A. et al. Mannheimia haemolytica and its leukotoxin cause macrophage extracellular trap formation by bovine macrophages. Infection and Immunity, v.80,n.5, p.1923-1933,2012.

20. CRADDICK, M. et al. Adenosine-5'triphosphate release by Mannheimia haemolytica, lipopolysaccharide, and interleukin-1 stimulated bovine pulmonary epithelial cells. Veterinary Immunology and Immunopathology,v.149, n.1-2,p.58-65,2012.

21. SINGH, K. et al. Cytokine expression by pulmonary leukocytes from calves challenged with wild-type and leukotoxin-deficient Mannheimia haemolytica. Veterinary Journal,v.192,n.1,p.112-119, 2012.

22. IRSIK, M. Bovine Respiratory Disease associated with Mannheimia Haemolytica or Pasteurella Multocida. Veterinary Medicine Animal Clinical Sciences Department,v.163,p.2-4,2010.

23. YOUSSEF, S.A. et al. Effect of bovine granulocyte colony-stimulating factor on the development of pneumonia caused by Mannheimia haemolytica. Veterinary Pathology,v.41,n.6, p.649-657,2004.

24. BATISTA, C.F. Dinâmica da resposta imune inata do sistema respiratório de bezerros. 2011.121f. Dissertação (Mestrado em Clínica Veterinária) - Faculdade de Medicina Veterinária e Zootecnia, Universidade de São Paulo, São Paulo, São Paulo.

25. BATISTA, C.F. et al. Maturation of mononuclear phagocytes in the lungs of young calves in vitro study. Journal Dairy Science, v.95, n.10, p.5909-5915, 2012.

26. REZENDE, M.L.G. Avaliação de parâmetros clínicos, hematológicos e viabilidade econômica do uso do florfenicol na metafilaxia das afecções respiratórias inespecíficas de bovinos confinados no estado de
Goiás. 2010. 45f. Tese (Doutorado) Escola de Veterinária, Universidade Federal de Goiás, Goiânia, Goiás.

27. PROHL, A. et al. The bovine lung in biomedical research: visually guided bronchoscopy, intrabronchial inoculation and in vivo sampling techniques. Journal of Visualized Experiments, n.89, p.1-11,2014.

28. BRODERSEN, B.W.Bovine Respiratory Syncytial Virus. Veterinary Clinics of North America: Food Animal Practice,v.26, n.2,p.323-333,2010.

29. RIDPATH, J. The contribution of infections with Bovine Viral Diarrhea Viruses to Bovine Respiratory Disease. Veterinary Clinics of North America: Food Animal Practice, v.26,n.2, p.335-348, 2010.

30. JONES, C.; CHOWDHURY, S. Bovine Herpesvirus type $1(\mathrm{BHV}-1)$ is an important cofactor in the Bovine Respiratory Disease Complex. Veterinary Clinics of North America: Food Animal Practice, v.26, n.2, p.303-321,2010.

31. WIKSE, S.E. Feedlot cattle pneumonia. Veterinary Clinics of North America: Food Animal Practice, v.1, n.2, p.289-310,1985.

32. CASWELL, J.L. et al. Mycoplasma bovis in respiratory disease of feedlot cattle. Veterinary Clinics of North America: Food Animal Practice, v.26, n.2, p.365-379, 2010.

33. GORDEN, P.J.; PLUMMER, P. Control, management, and prevention of bovine respiratory disease in dairy calves and cows. Veterinary Clinics of North America:Food Animal Practice, v.26, n.2,p.243-259, 2010.

34. RICE, J.A et al. Mannheimia haemolytica and bovine respiratory disease. Animal Health Research Reviews, v.8,n.2,p.117-128,2007. 
35.TAYLOR,J.D. et al. Nasal isolation of Mannheimia haemolytica and Pasteurella multocida as predictors of respiratory disease in shipped calves. Research in Veterinary Science, v.99, p.41-45, 2015.

36. TESFAYE, B. et al. Diversity of bacterial species in the nasal cavity of sheep in the highlands of Ethiopia and first report of Histophilus somni in the country. Tropical Animal Health and Production, v.45, n.5, p.1243-1249,2013.

37. GRIFFIN, D. Bovine pasteurellosis and other bacterial infections of the respiratory tract. Veterinary Clinics of North America: Food Animal Practice, v.26, n.1, p.57-71,2010.

38. NORDLUND, K.V.; HALBACH, C.E. Calf barn design to optimize health and ease of management. Veterinary Clinics of North America: Food Animal Practice, v.35, n.1, p.29-45,2019.

39. McGUIRK, S.M. Disease management of dairy calves and heifers. Veterinary Clinics of North America: Food Animal Practice,v.24, n.1,p.139-153,2008.

40. LOVE, W.J. et al. Development of a novel clinical scoring system for on-farm diagnosis of Bovine Respiratory Disease in pre-weaned dairy calves. PeerJ, v.2, p.e238,2014.

41. OLLIVETT, T. Understanding the diagnosis and risk factors for respiratory disease in dairy calves. 2014. 153f. Thesis (PhD) - University of Guelph, Ontário, Canadá.

42. BRSCIC, M. et al. Prevalence of respiratory disorders in veal calves and potential risk factors. Journal Dairy Science, v.95, n.5, p.2753-2764,2012.

43. ANGEN, Ø. et al. Respiratory disease in calves: microbiological investigations on trans-tracheally aspirated bronchoalveolar fluid and acute phase protein response. Veterinary Microbiology, v.137, n.1, p.165$171,2009$.

44. GODINHO, K.S. et al. Use of deep nasopharyngeal swabs as a predictive diagnostic method for natural respiratory infections in calves. Veterinary Record, v.160, n.1,p.22-25,2007.

45. LERUSTE, H. et al. The relationship between clinical signs of respiratory system disorders and lung lesions at slaughter in veal calves. Preventive Veterinary Medicine,v.105, n.1-2,p.93-100, 2012.

46. FAGLIARI, J.J. Estudo clínico e laboratorial da pneumonia de bezerros induzida pela inoculação intrabronquial de Mannheimia haemolytica. Arquivos Brasileiro de Medicina Veterinária e Zootecnia, v.55, n.1, p.814,2003.

47. HANZLICEK, G.A. et al. Serial evaluation of physiologic, pathological, and behavioral changes related to disease progression of experimentally induced Mannheimia baemolytica pneumonia in postweaned calves. American Journal of Veterinary Research, v.71, n.3, p.359-369,2010.

48. KOTERBA, A.M.Identificação do neonato de alto risco. Distúrbios e tratamento do neonato. In: SMITH B.P.Tratado de Medicina Interna de Grandes Animais. $1^{a}$ ed. São Paulo: Manole, 1993,pp. 299-301.

49. GONÇALVES, R.C. et al. Lavagem traqueobrônquica por sondagem nasotraqueal em bezerros. Arquivos Brasileiro de Medicina Veterinária e Zootecnia, v.56, n.3,p.307-311,2004.

50. BENESI, F.J. et al. Microbiota bacteriana e citologia da região traqueobrônquica de bezerros no período 
neonatal. Pesquisa Veterinária Brasileira, v.33, n.6, p.700-704,2013.

51. BENESI, F.J. et al. Citologia dos lavados traqueobrônquico (LTB) e broncoalveolar (LBA) de bezerros holandeses sadios durante o primeiro mês de vida. Pesquisa Veterinária Brasileira,v.32,n.3, p.267-270, 2012.

52. BATISTA, C.F. et al. Doença respiratória dos bezerros. Nosso Clínico,v.3, n.13, p.4-10,2010.

53. VIANNA, R.S. et al. Pulmonary cytological profile of healthy calves in the first three months of life. Pesquisa Veterinária Brasileira,v.36, n.5,2016.

54. GONÇALVES, R.C. Estudo clínico e citológico em bezerros clinicamente sadios e portadores de broncopneumonia moderada e grave: o lavado traqueobrônquico como complemento diagnóstico. 1997. 144f. Tese (Doutorado em Patologia) - Faculdade de Medicina Veterinária e Zootecnia, Universidade Estadual Paulista Júlio Mesquita Filho, Botucatu, São Paulo.

55. GONÇALVES, R.C.; FEITOSA, F.L.F. Semiologia do sistema respiratório de grandes animais. In: FEITOSA, F.L.F. Semiologia Veterinária: a arte do diagnóstico.2aed. São Paulo: Roca,2008,pp.275-306.

56. COOPER, V.L.; BRODERSEN, B.W. Respiratory disease diagnostics of cattle. Veterinary Clinics of North America: Food Animal Practice, v.26, n.2, p.409416,2010.

57. FAGLIARI, J.J. et al. Serum protein concentrations in calves with experimentally induced pneumonic pasteurellosis. Arquivos Brasileiro de Medicina Veterinária e Zootecnia, v.55, n.4,p.383-387,2003.

58. THRUNAVUKKARASU, P. et al. Bronchoscopic findings in bovine respiratory disorders. Indian Veterinary Journal,v.82,p.1206-1207,2005.

59. BATISTA, C.F. et al. Avaliação endoscópica do sistema respiratório de bovinos sadios. Revista de Educação Continuada em Medicina Veterinária e Zootecnia do $C R M V-S P$, v.14,n.3, p.36-41,2016.

60. FRANZ, S. Endoscopy in cattle. Tierärztliche Praxis Ausgabe G: Großtiere/Nutztiere,v.39, n.5, p.281-288, 2011.

61. FRANZ, S. Endoscopy in ruminants - Endoscopy of the respiratory tract in cattle: indications, possibilities and limits. Tierarztl Umsch, v.68, n.10, p.411-416, 2013.

62. COUTINHO, A.D.S. et al. Mannheimiose pulmonar experimental em bezerros: swab nasal e nasofaringeano como auxílio diagnóstico. Pesquisa Veterinária Brasileira, v.29, n.1,p.83-88,2009.

63. PARDON, B.; BUCZINSKI, S. Bovine respiratory disease diagnosis: what progress has been made in infectious diagnosis? Veterinary Clinics of North America: Food Animal Practice, v.36, n.2, p.425-444, 2020.

64. VAN DRIESSCHE, L. et al. A deep nasopharyngeal swab versus nonendoscopic bronchoalveolar lavage for isolation of bacterial pathogens from preweaned calves with respiratory disease. Journal of Veterinary Internal Medicine, v.31, n.3, p.946-953,2017.

65. RABELING, B. et al.Ultrasonographic findings in calves with respiratory disease. Veterinary Record, v.143, n.17,p.468-471, 1998.

66. OLLIVETT, T.L.; BUCZINSKI, S. On-farm use of ultrasonography for bovine respiratory disease. Veterinary Clinics of North America: Food Animal Practice, 
v.32,n.1,p.19-35,2016.

67. OLLIVETT, T.L. et al. Thoracic ultrasonography and bronchoalveolar lavage fluid analysis in Holstein calves with subclinical lung lesions. Journal of Veterinary Internal Medicine, v.29, n.6, p.1728-1734, 2015.

68.ANDRADE,J.P.Métodos de diagnóstico na avaliação pulmonar de bezerros. 2017. 76f. Dissertação (Mestrado em Medicina Veterinária) - Escola de Veterinária, Universidade Federal de Minas Gerais, Belo Horizonte, Minas Gerais.

69. CARDOSO,M.V.et al.Importância do diagnóstico diferencial em um surto de pneumonia enzoótica bovina. Arquivos do Instituto Biológico, v.69, n.3, p.111113,2002.

70. ILLAMBAS, J. et al. Pharmacodynamics of marbofloxacin for calf pneumonia pathogens. Reserach Veterinary Science, v.94, n.3,p.675-681,2013.

71. OZKANLAR, Y. et al. Bovine respiratory disease in naturally infected calves: clinical signs, blood gases and cytokine response. Revue de Médecine Vétérinaire, v.163,n.3,p.123-130,2012.

72. WALLAMECQ, H. et al. How transcriptomic studies may halp to improve the control of bovine diseases: anexample with alf pneumonia and endotoxemia. Hungarian Veterinary Journal, n.130, supl.1, p.75-76, 2008.

73. BATISTA, C.F. Dinâmica de fagócitos sanguíneos e alveolares em bezerros com mannheimiose. 2015 . 145f. Tese (Doutorado em Clínica Veterinária) Faculdade de Medicina Veterinária e Zootecnia, Universidade de São Paulo, São Paulo, São Paulo. piratory infections in cattle. In: XXIV WORLD BUIATRICS CONGRESS, 2006, Nice, France. Anais... Nice:2006.p.384-397.

75. GODDEN, S.M. et al. Colostrum management for dairy calves. Veterinary Clinics of North America: Food Animal Practice,v.35, n.3,p.535-556,2019.

76. GOMES, V. et al. Doenças na fase de aleitamento e práticas de adaptação e asfixia neonatal. Revista Brasileira de Buiatria,v.1,n.2,p.1-36,2021.

77. COUTINHO, A.S. Complexo das doenças respiratórias de bezerros. In: II SIMPÓSIO MINEIRO DE BUIATRIA, 2005. Belo Horizonte. Anais... Belo Horizonte:2005.p.1-19.

78. RICHESON,J.T.; FALKNER, T.R. Bovine respiratory disease vaccination: what is the effect of timing? Veterinary Clinics of North America: Food Animal Practice,v.36,n.2,p.473-485, 2020.

79. CHAMORRO, M.F.; Palomares, R.A. Bovine respiratory disease vaccination against viral pathogens modified-live versus inactivated antigen vaccines, intranasal versus parenteral, what is the evidence? Veterinary Clinics of North America: Food Animal Practice, v.36,n.2,p.461-472, 2020.

80. GOMES, R.C. Influência etária na resposta imunológica de bezerros à vacinação intranasal.2016.145f. Tese (Doutorado em Clínica Veterinária) - Faculdade de Medicina Veterinária e Zootecnia, Universidade de São Paulo, São Paulo, São Paulo.

81. NETEA, M.G. et al. Trained immunity: a program of innate immune memory in health and disease. Science,v.352, n.6284, aaf1098-aaf1098,2016.

82. CHEN,J.et al. Expression of the bovine NK-Lysin 
gene family and activity against respiratory pathogens. PLoS One,v.11, n.7,e0158882,2016.

83. DASSANAYAKE, R.P. et al. Antimicrobial activity of bovine NK-lysin-derived peptides on Mycoplasmabovis. PLoS One, v.13, n.5, e0197677,2018.

84. PESCIAROLI, M. et al. Tuberculosis in domestic animal species. Research in Veterinary Science, v.97, supl.,p.78-85,2014.

85. ANTUNES, J.L.F. et al. Tuberculose e leite: elementos para a história de uma polêmica. História, Ciências, Saúde Manguinhos, v.9, n.3,p.609-623,2002.

86. BRASIL. Ministério da Agricultura, Pecuária e Abastecimento. Programa Nacional de Controle e Erradicação da Brucelose e da Tuberculose Animal (PNCEBT). 1ªed. Brasília: MAPA/SDA/DSA, 2006. $188 \mathrm{p}$.

87. MADIGAN, M.T. et al. Microbiologia de Brock. 10aed. São Paulo: Pearson, 2004.

88. OLEA-POPELKA, F. et al. Zoonotic tuberculosis in human beings caused by Mycobacterium bovis - a call for action. Lancet Infectious Diseases, v.17, n.1, p.21-25, 2017.

89. BRASIL. Ministério da Agricultura, Pecuária e Abastecimento. Diagnóstico situacional do PNCEBT: Programa Nacional de Controle e Erradicação da Brucelose e da Tuberculose Animal (PNCEBT). 1ªed. Brasília:MAPA/SDA/DSA,2020.102p.

90. MURAKAMI, P.S. et al. Tuberculose bovina: saúde animal e saúde pública.Arquivos de Ciências Veterinárias e Zoologia da UNIPAR, v.12, n.1, p.67-74, 2009.
91. RODRIGUES, R.A. et al. False-negative reactions to the comparative intradermal tuberculin test for bovine tuberculosis. Pesquisa Veterinária Brasileira, v.37, n.12,p.1380-1384,2017.

92. MAYER, F.Q. et al. Nasal swab real-time PCR is not suitable for in vivo diagnosis of bovine tuberculosis. Pesquisa Veterinária Brasileira, v.37, n.6, p.549-554, 2017.

93. RUSSEL, A.D. et al. (Eds.). Guidelines on Disinfection in Animal Husbandry for Prevention ans Control of Zoonotic Diseases. Geneve: World Health Organization, 1984.64p. 


\section{Catofós ${ }^{\circledR}$}

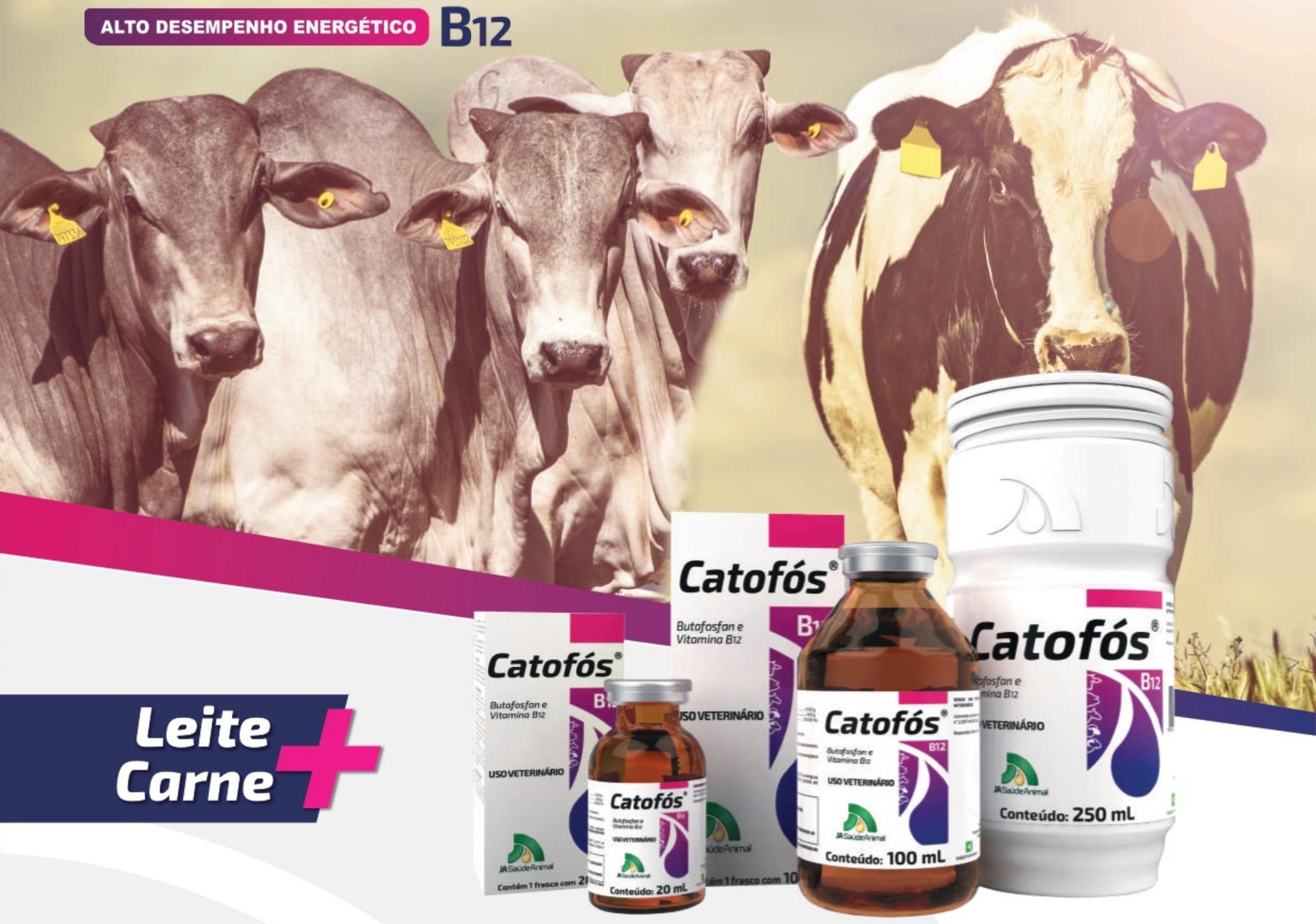

* Ação imediata $\approx$ Aumento dos índices e alta eficácia produtivos e reprodutivos
* Redução do estresse

Catofós ${ }^{\circledR}$ B12 é uma solução injetável à base de Butafosfan (Fósforo Orgânico) e Vitamina B12, promovendo alta eficácia na prevenção e tratamento dos estados carenciais de Fósforo e Cianocobalamina.

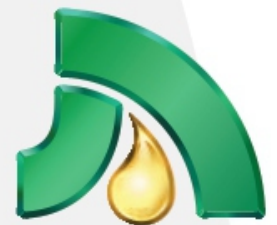

JASaúdeAnimal 